\title{
Böszörményi zsiványnyelvi szójegyzékek
}

\author{
KIS TAMÁS
}

1. A magyar tolvajnyelv legkorábbi hiteles emlékei a 18. század utolsó harmadából származó zsiványnyelvi szójegyzékek (KIS 2020: 274-281), amelyeknek értékét az is növeli, hogy ezt a néhány glosszáriumot közel száz évig nem követték hasonlók: majd csak a 19. század második felében találkozunk nagyobb mennyiségben újabb, ám korántsem ilyen közvetlen forrásból származó tolvajnyelvi adattal (vö. TORONYAI 1862: 27-33, BERKES 1888: 98-182).

A zsiványnyelvi szavak gyüjtésének fő oka a 18. században (és utána még hosszú ideig) a tolvajok könnyebb felismerése, elfogása és az elfogottak bünösségének bizonyítása volt. A szójegyzékek összeállítói abból a feltevésből indultak ki, hogy aki a bünözők nyelvét ismeri, használja, az maga is bünözö, azaz felismerték, hogy a nyelv nem egyszerủen csak információközlésre szolgál, hanem identitásjelző eszköz is, a csoporthoz, közösséghez tartozás pregnáns kifejezője (KIS 2001: 251-252). Éppen ezért a bandákba szerveződött vásári tolvajok (vagy a saját magukra használt megnevezéssel: zsiványok) elleni perekben a bíróságok különös figyelmet fordítottak a tolvajnyelv megismerésére. ${ }^{1}$

2. A zsiványokról a korabeli periratokból tudjuk, hogy vásárokról vásárokra jártak, és loptak mindent, ami mozdítható volt: pénzt, szövetet (gyolcsot), szoknyát, nadrágot, csizmát, kalapot, szürt, bármit. Ha úgy adódott, a szekerekről a lezárt ládát is ellopták, amit aztán később egy nyugalmas helyen feltörtek, de a zsebtolvajlás, zsebmetszés vagy a részegek kifosztása is szokásos tevékenységük közé tartozott.

A fennmaradt iratokban megnevezett vásári tolvajok száma a százat is megközelíti. ${ }^{2}$ Ezek a bünözők alkalmilag egy-egy vásárban vagy vásárba menve kisebb csoportokba verődtek, mert a lopások sikeres elkövetéséhez több személy

\footnotetext{
${ }^{1}$ A magyar igazságszolgáltatás képviselőinek érdeklődését a bűnözők nyelve iránt jól mutatja, hogy 1783-ban a német argóról (Diebessprache) is készült hasonló szójegyzék (Kis 2001, HofFMANN-KIS 2009).

${ }^{2}$ A zsiványok nagy számáról a bűneiért 1776-ban halálra ítélt Czagány András így nyilatkozott: „Ha Böszörménytől fogva Nánásig csináltatnák az Akasztó fát, még sem férne reá, ha mind fel aggatnák" (HBML IV. A. 1018/d. 2. cs.).
} 
„munkamegosztására” volt szükség, majd dolguk végeztével osztoztak a zsákmányon. Az egyik 1775-1776-os egri per jegyzőkönyvéből az is kiderül, hogy sokan egy országos kiterjedésü, szervezett bandába tartoztak, amely kompániának fővezére és alvezérei voltak, tagjai esküt tettek, „tolvajiskolát” müködtettek, jutalmazták a hallgatást a vallatások során, ${ }^{3}$ az újoncokat a tolvajlás trükkjein ${ }^{4}$ túl a zsiványnyelvre is megtanították ${ }^{5}$ stb. Természetesen nem minden vásári tolvaj tartozott ebbe a péterváradi vezér által irányított bandába, ${ }^{6}$ de a különböző kisebb-nagyobb ${ }^{7}$ társaságokba tömörülő zsiványok ismerték egymást. ${ }^{8}$

Ez a tisztességes társadalomtól viszonylag elkülönülö, erősen összetartó csoportokba való szerveződés lehetett a legfőbb oka annak, hogy a vásári tolvajok között kialakult a rájuk jellemző (saját elnevezésükkel) nyalavinyelv, amit ők maguk és a bíróságok is a zsiványokhoz tartozás azonosító jegyeként ismertek el. ${ }^{9}$ A 18. századi vásári tolvajok zsiványnyelve országosan többé-kevésbé egy-

${ }^{3}$ „Ha valamelyiketek rabságban többi Társaid ellen nem vall semmit, vané valami jútalma annak, es kitül? - Igen is van jutalma; Es az ollyanokat a Tiszt[art]o szokta jutalmazni, s pénzt adni nékiek." (BFL IV. 1223. e. 13. d., 1552. cs., 1. irat, 17. oldal; ugyanez: MNL HML XII-3/b. 16. d., C/1. cs., 12. oldal).

${ }^{4}$ „Ollyan Sivány is az Oláh Bokor Judith, hogy nállánál nagyobb sem kell eö tanitott engemet erre' a' Siványságra, eö volt a' Praeceptorom mert már eö az elött is jól tudott hozzá" (MNL OL C 43 - Acta secundum referentes - Sauska - 1782 - Fasc. 62.).

5 ,én ezektül tanúltam a ZSivány Nyelvet, ugy mint Ujvárasi Miskátúl, Czipo Samutúl, és Joskátúl, a kik nékem Le irták papirosra, mivel tudtam olvasni” (MNL HML XII-3/b. 16. d., C/1. cs., 3. oldal; ugyanez: BFL IV. 1223. e. 13. d., 1552. cs., 1. irat, 24. oldal).

${ }^{6}$ „Az leg föllebb valo ZSivanyt kinek hijak közületek? — Lakatosnak nevezik [...] ritkan ZSivánkodik maga hanem eö hozzá hordják a ZSivanyságot S minden lopott jószágoknak fele az ővé, Péterváran allandoúl lakik Zsellérségben a Magyari Uczában a pirosi Kapunál: Tud Magyarúl Ráczúl, Németül Deákúl. Eő petsétet tart, irást tud, a többi ZSiványok[na]k Passusokat ád, az Császár hajós Kormanyossának irja magát lenni, ez mindenkor tizenkét tanitványokat tartt, és tanitt maga mellett, kiket vonyó, vagy is hajó huzó legények[ne]k nevez lakatosnak pedig hivattattik, mert annak előtte Lakatos Mester ember volt Sármelyéken Fejér Vármegyében Ennek oskolájában Panni Dorkával én is voltam Péterváran valami két hetig, az egész tolvaj Compagniának nevei Eő nála vannak föl irva. Ez parancsol mint a Tiszt[art]onak, mind a Kajszernek ki Után ezen Kettőt nagyobbak[na]k tartúnk tőbbínél.” (BFL IV. 1223. e. 13. d., 1552. cs., 1. irat, 14-15. oldal; ugyanez: MNL HML XII-3/b. 16. d., C/1. cs., 12. oldal).

${ }^{7}$ Egy-egy banda akár meglehetősen kiterjedt is lehetett. Vö. „Mennyiböl áll az a Reszegi Zsivány Companiaja? (...) Csak emlékezzél reá, a’ többiekre is, mert azt mondgyák hogy az az eö Companiaja Tokajtul fogva a Dunáig tart?" (MNL OL C 43 - Acta secundum referentes - Sauska - 1782 - Fasc. 62.).

${ }^{8}$ „A Szemérül is meg ismérem, Ha' Rea nezek, nem is ugy beszelnek eők mint mide nem Ertem a' beszédgyeket, és Sokad magokkal szoktak járni” (MNL SzSzBML IV. 9. cc. 63. d., Fasc. 8., № 70., 6. oldal), „,egymást egymás nyelvérülmeg ismérjük, és oszve akadván mindgyárt megismérjük egymást" (uo. 15. oldal).

9 „mind a' nyelvet tudja, mind hasonló Sivány” (MNL HBML HbFl IV. A. 505/e. 16. d., 1776. № 14., 20r). „A’ Hajdú Városokon bizonyos ZSiványokat vagy is Vásári Tolvajokat meg fogtak, kik magokba térvén ki vallották hogy mitsoda Terminusokkal magok kőzőtt szoktak élni: arra nézve F.[ölséges]H.[elytartó]K.[irályi] Magyar Tanátsnak Kegyelmes Parantsolattyából azon kőzőttők folyó Terminusok vagy is szók a' végre hirdetteknek K[egye]l[me]tek kőzőtt hogy azok- 
séges és elterjedt lehetett ${ }^{10}$ köszönhetően annak, hogy e tolvajok szerte az országban ${ }^{11}$ megfordultak.

Más bünözők (ló- és marhatolvajok, pincefeltörők, betörők stb.) körében a tolvajnyelvnek semmilyen nyomát nem találtam ebben a korban a levéltári iratokat lapozgatva. Még a későbbi, 19. századi betyárok nyelvéről sincsenek adataink, jóllehet esetükben tudunk nagyobb létszámú bandák létezéséről, és ez alapján feltételezhetnénk közöttük valamiféle saját csoportnyelv meglétét. ${ }^{12}$ Majd az 1800-as évek második felében feltünő városi bünözés és bünbandák hoztak létre egy olyan - egyébként erősen német hatás alatt álló - tolvajnyelvet, amelyet legkorábbi tolvajnyelvi szótáraink mutatnak be (JENÖ-VETÖ 1900, Államrendörség 1911).

3. A 18. század utolsó harmadából származó zsiványnyelvi szójegyzékek keletkezése annak köszönhető, hogy 1775 és 1777 között Magyarország számos településén (Balkány, [Hajdú]Böszörmény, Debrecen, Eger, Miskolc, [Tisza]Nagyfalu, Nagykálló, [Hajdú]Nánás, Pest, Szügy, Újfehértó stb.) folytak eljárások és büntető perek vásári tolvajok ellen. Három városban: Miskolcon, Egerben és Böszörményben a perben részt vevő hivatalos személyek úgy döntöttek, hogy a vádlottak által használt tolvajnyelvi szavakból külön listát állítanak öszsze. A vallatások vezetői rákérdeztek a zsiványnyelv ismeretére, ${ }^{13}$ és a jegyzőkönyvek tanúsága szerint a vád alá helyezett személyeknek efféle kérdéseket tettek fel: „Hát Zsiván Nyelven beszélleni hol tanúltál? — Egyéb helyen, s egyéb képpen nem tanúlta[m], hanem mióta Veszprémyhez állottam azóta tőllők tanúlta[m] egynyehány szót". ${ }^{14}$ A jegyzőkönyvekben magára a zsiványnyelvre is találunk adatokat: „Azon idegen SZokon beszéllő Tolvajóknak

ról azon Vásári káros Tolvajokat leg hamarébb észre vehessék, és mihelyest valakitől ollyas Terminusokat hallananak azonnal megragattassák" (OSZK, Fol. Hung. 1581., 4. füzet, 45v).

${ }^{10}$ „Még másutt ezen a’ részen kívül hol vetted észre hogy illyen Sivány Tolvajok vagynak? és ezt a Nyelvet értik? - Tudom, hogy mikor Székes Fehér Vármegyében vóltam kvartéllyban ott leg tőbbet láttam, és ott is ez a' Nyelv vagyon." (MNL OL C 43 - Acta secundum referentes Sauska - 1782 - Fasc. 62.).

${ }^{11}$ Miként az egyik vásári tolvaj vallotta: a zsiványok ,az egész országban el szoktak szélledni; Sőtt Horváth, Erdély és Lengyel, s tőbb országokban is elegen vadnak Kőzűlők, az országban szoktak Gyakrabban meg fordulni Kecskeméten Pesten nappal az Invalidában a’ Korcsmákban SZoktak lenni, ejjel SZélledve az a Vásárban: Szegeden Péter Várán, Győrőt Komáromban, Fejér Várott, Veszprémben, Pápán, Miskolczon Debreczenyben Váradon Tokajban, és ezek mind változott nevekkel élnek." (BFL IV. 1223. e. 13. d., 1552. cs., 1. irat, 8-9. oldal; vö. MNL HML XII3/b. 16. d., C/1. cs.). A jegyzőkönyvekben megnevezett településeket nézve is láthatjuk, hogy Szatmárnémetitől Győrig, Kassától Újvidékig terjedt a vásári tolvajok tevékenységi területe.

${ }^{12}$ A próbálkozások, amelyek a betyárok nyelvét akarták bemutatni, sikertelennek tekinthetők (lásd TÖMÖRKÉNY 1898: 37-48, 85-93, SIKLÓSSY 1933, vö. még LEHR 1914) .

13 „Sivány vagy e', és tudode’ a' Sivány nyelvet?” (MNL SzSzBML IV. 9. cc. 63. d., Fasc. 8., № 38., 3. oldal).

${ }^{14}$ MNL HML XII-3/b. 15. d. e/8. cs., 18. oldal. 
Beszedjékrül, mit tudsz, mit hallottál? beszéldel. — Egyebet nem tudok, nem is hallottam azon SZórul, hanem hogy egyszer előttem az utban a' Pista a' Disznot SZuszogonak hivta az őkrőt pedig SZőrősnek vagy minek hivta, és egymás kőzőtt Jancsival ezen a beszeden beszélgettek". ${ }^{15}$

A büntető eljárások során a különböző településeken folyó pereket összekapcsolták, a bíróságok egymás között információkat cseréltek, leveleztek, vallomás- és iratmásolatokat küldtek egymásnak, hiszen a perbe fogott vádlottak nem egy esetben ismerték egymást, együtt loptak, élettársak voltak, időnként közösen vándoroltak, esetleg (idény- vagy alkalmi) munkát végeztek ugyanazon a helyen stb. A bíróságok által egymásnak megküldött anyagban minden bizonnyal ott szerepeltek a ma ismert szójegyzékek másolatai is. Erre tesz utalást 1775. december 6-án Almásy József, ezt írván Vécsey László egri püspöki fiskálisnak Miskolcról küldött levelében: „az adnectalt ${ }^{16}$ Vocabulat kedvesen veszük, melyet ha együve Kapcsolúnk az nálunk le irot Szavakkal, majd közel egy Nyelv telik belüle ezel." ${ }^{\prime 17}$

4. Eddigi ismereteink szerint a 18. századból három zsiványnyelvi szójegyzék(csoport) maradt fenn. Az a nyelvészek között élő hiedelem, hogy e korai tolvajnyelvi szójegyzékek száma ennél jóval nagyobb, annak köszönhető, hogy a Böszörményi szójegyzéket a Helytartótanács 1782-ben kinyomtatta, és egy körlevél mellékleteként országszerte szétküldte, így erröl jó néhány (többnyire számos hibát is tartalmazó) kéziratos másolat készült az egyes települések protocollum currentaliumaiba, amiket aztán a 20. század folyamán egymástól független tolvajnyelvi szójegyzékként fedeztek fel és adtak közre a kutatók.

Az egyes zsiványnyelvi szójegyzékek születésének idejét a rajtuk szereplö dátumozásból pontosan ismerjük, a szójegyzékeket tartalmazó iratcsomókban fellelhető további periratok alapján pedig keletkezési körülményeikre vonatkozóan is találhatunk információkat. A szójegyzékek készítői vélhetőleg támaszkodtak egymás gyüjteményeire (vagy legalábbis tudtak létezésükről, mint erre ez imént idézett miskolci levélrészlet is utal), de közvetlen, direkt másolás csak az egy csoportba tartozó szójegyzékek között figyelhető meg. (A szójegyzékek összefoglaló áttekintését lásd az 1. ábrán a 199. oldalon.)

4.1. Első ismert zsiványnyelvi emlékünk a Miskolci szójegyzék (MiskSzj.). Ez az 1775. május 9-ére dátumozott, a 28 adatában 28 különböző zsiványnyelvi szót (28 önálló lexémát) tartalmazó, kézzel írott szójegyzék a Nógrád Megyei Levéltárban őrződött meg egy Szügyön tárgyalt per anyagai közöttt, ${ }^{18}$ szövegét TÖRÖK GÁBOR tette közzé 1957-ben.

${ }^{15}$ MNL HML XII-3/b. 15. d. e/7. cs., 7. oldal.

${ }^{16}$ adnectalt 'mellékelt'.

${ }^{17}$ MNL HML XII-3/b. 15. d., e/1. cs.

${ }^{18}$ MNL NML IV. 13. 12. d., Fasc. XLV. 36/1777, № 8., 12. oldal. 
4.2. A MiskSzj.-et időben egy négy példányból (négy különálló szójegyzékből) álló, 281 adatot (86 lexémát) tartalmazó szójegyzékcsoport, az Egri szójegyzékek (EgriSzj.) követi. Ennek második és harmadik példánya az első példánynak közvetlen, az eredeti kéziratban látható módosítások alapján javított másolata. Ezt a három példányt I. Egri szójegyzékek-ként említhetjük. A negyedik példány, a II. Egri szójegyzék egy az előbbiektől némiképpen eltérő változat, de különbségei inkább formaiak, a szókészletet alig érintik, ezért ezt önálló szójegyzéknek nem tekinthetjük. (Az EgriSzj.-ről részletesebben lásd KIS 2020.)

4.2.1. Az első három egri szójegyzék 1775 . november 28-i keltezésü, a bennük felsorolt adatok a vásári tolvajlásért elfogott Kovács János püspöki menedéket kérő fogolytól származnak. Az első példányt tekinthetjük az eredetinek (sőt a benne látható nagyszámú javítás miatt piszkozatként is felfoghatnánk, ha nem a hivatalos iratok között maradt volna fenn), amelyröl két másolat (tisztázat) készült, azonban ezek nem teljesen egyformák, mert lemásolásuk az eredeti példány különböző javítottsági fokán történt. Az I. Egri szójegyzékek (EgriSzj.I.) három példánya 208 adatot (72 lexémát) tartalmaz.

4.2.1.1. A 2020-ban fellelt I-1. Egri szójegyzék (EgriSzj.I-1.) a Heves Megyei Levéltárban található, ${ }^{19} 67$ sorában a módosításokkal, betoldásokkal együtt összesen 70 adat (68 lexéma) szerepel. Szövegét a lejegyzéssel egy időben történt javításokon kívül még legalább további három alkalommal változtatta meg és egészítette ki vélhetőleg az eredetit is jegyző kéz. (A szöveg közlését lásd KIS 2020: 282-285.)

4.2.1.2. A SCHRAM FERENC által 1962-ben publikált I-2. Egri szójegyzék-et (EgriSzj.I-2.) a Piarista Rend Magyar Tartománya Központi Levéltára őrzi, ${ }^{20}$ ezért - hiszen 2020-ig nem volt ismeretes sem a forrása, sem keletkezésének helye - Piarista szójegyzék néven tartotta számon a szlengkutatás. A szójegyzék 70 sorában 71 adat olvasható, ami az ismétlődések miatt 69 lexémát jelent. Az EgriSzj.I-2.-nek az előzmény EgriSzj.I-1.-től való lényeges eltéréseként a szöveg végére pótlásként beírt négy adatot említhetjük, a szöveg többi részében a szójegyzék az eredeti példánynak a második javítás utáni pontos másolata.

4.2.1.3. Az I-3. Egri szójegyzék (EgriSzj.I-3.) nem más, mint a piszkozati példány (azaz az EgriSzj.I-1.) végső tisztázata, készítője ugyanaz a személy volt, aki az eredetit is leírta. A „piszkozathoz” hasonlóan 2020-ban megtalált, 66 sorban 67 adatot (de egy ismétlődés miatt csak 66 lexémát) tartalmazó EgriSzj.I-3. is a Heves Megyei Levéltárban található. ${ }^{21}$ (A szöveg közlését lásd KIS 2020: 282-285.)

\footnotetext{
${ }^{19}$ MNL HML XII-3/b. 16. d., C/1. cs.

${ }^{20}$ PMKL I.1.a, For. 43 (Varia), Fasc. 1., № 16.

${ }^{21}$ MNL HML XII-3/b. 15. d., e/1. cs.
} 
4.2.2. Az Egri szójegyzékek közé tartozik még a szakirodalomban korábban is Egri szójegyzék-ként említett és 19. század elejiként számon tartott (valójában azonban - mint ez napjainkra tisztázódott - 1775. november 29-i keltezésü) II. Egri szójegyzék (EgriSzj.II.), amely Raphaëlis Takáts 1811-ben keletkezett kéziratos Lexicon Ungaricumában található az MTA kézirattárában egy a könyv végére betett, önálló, de a könyv 310 . leveleként beszámozott lapon. ${ }^{22}$ Ez a szójegyzék nem közvetlen másolata a másik három egri zsiványszójegyzék-példány egyikének sem (talán erre utal a címében használt Dictionarium Novum 'új szótár' kifejezés is), keltezési dátuma is egy nappal későbbi. Eltéréseinek jelentős része azonban csak „,szerkezeti” jellegü: a november 28-i datálású három példány és a november 29-i dátummal jegyzett szójegyzék szavai között majdnem teljes egyezést találunk, pusztán a szavak sorrendje tér el, bár több terjedelmes blokkon belül még ez a sorrend is azonos. Emiatt a HEINLEIN ISTVÁN által 1908-ban publikált, 71 sorában 73 adatot/lexémát felsoroló EgriSzj.II.-nek önálló, az Egri szójegyzékek nyelvemlékcsoporton kívüli számontartása nem indokolt. (Az EgriSzj.I. és az EgriSzj.II. összefüggéseiről lásd KIS 2020: 275-281.)

4.3. A harmadik 18. századi zsiványnyelvi szójegyzékcsoport Böszörményben (ma: Hajdúböszörmény) készült: a többszöri javítások nyomát magán viselő I. Böszörményi szójegyzék (saját címe szerint: Zsivány Szók) 1776-ban, majd ennek kéziratos másolata és az erröl készült nyomtatott változat, a II. Böszörményi szójegyzékek 1782-ben. Ez utóbbi, Hajdúsági vagy az aláíró főjegyzőről Jablonczay-féle szójegyzék-ként is ismert zsiványnyelvi emlékünk országos hírnévre tett szert: több másolatát megtalálták és tették közzé a nyelvészeti folyóiratokban, érdekességként napilapokban közölték, sőt Dugonics András révén hamar bevonult a szépirodalomba is. Ez a szójegyzékcsoport összesen 240 adatot tartalmaz, az ezekben előforduló lexémák száma 80-98 között van, attól függően, hogy mely alakváltozatokat számoljuk egybe vagy külön (vö. coff/caff, kasznya/kasnya, perge/pergö, pléde/plédez stb.).

Annak ellenére, hogy sokan máig úgy tudják, hogy az 1782-es Jablonczayféle szójegyzék az első magyar tolvajnyelvi emlékünk (pl. BOROSS-SzÜTS 1987: 10), a Böszörményi szójegyzékek (BöszSzj.)-nek együttes, filológiailag megbízható közzététele eddig még nem látott napvilágot. Mostani munkámban ezt a hiányt szeretném pótolni.

${ }^{22}$ MTA KIK Kézirattár és Régi Könyvek Gyüjteménye, jelzete: M. Nyelvt. 4-r. 33. sz. 


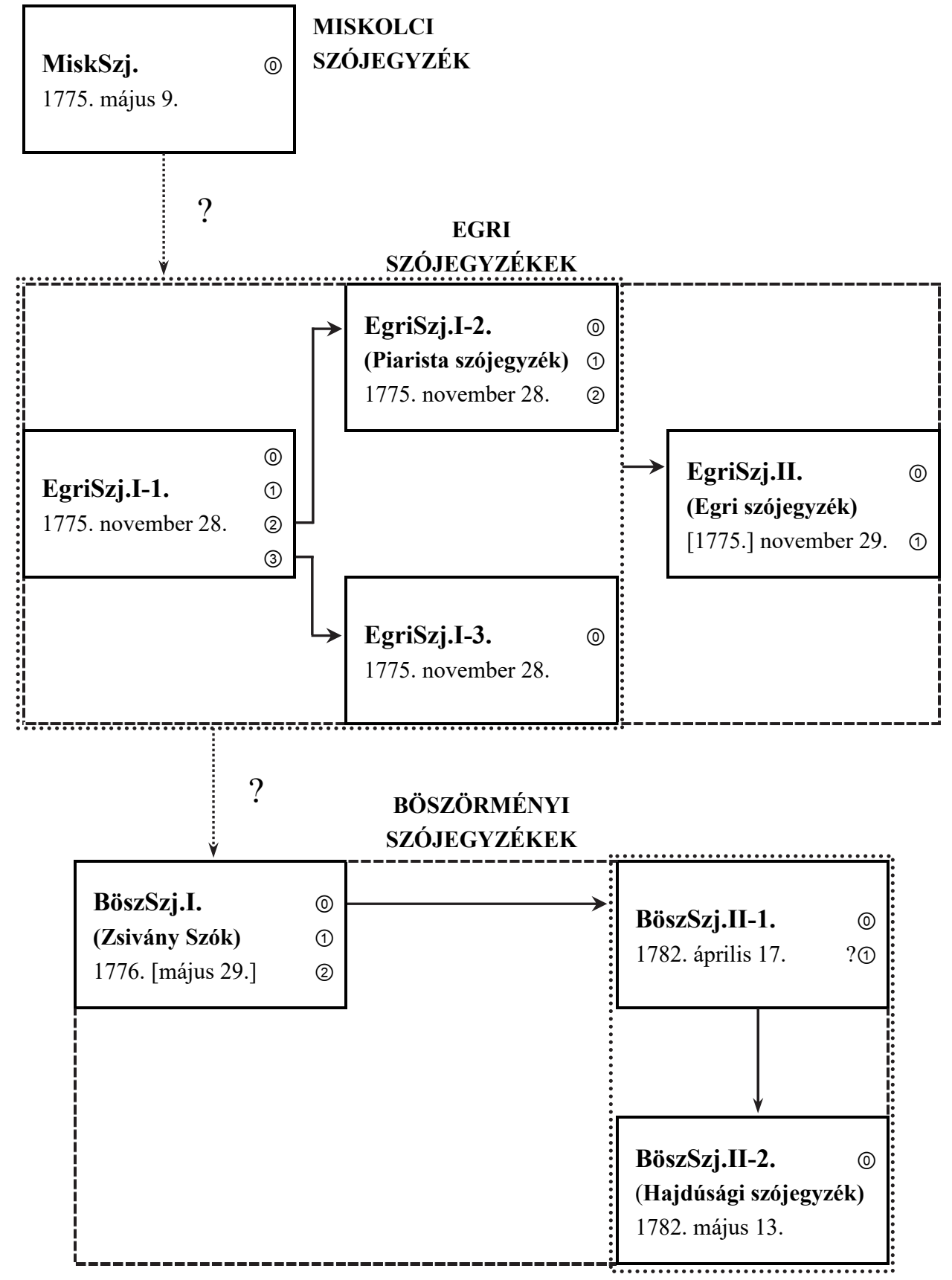

1. ábra. Zsiványnyelvi szójegyzékek. (A számok az adott példány módosításait jelzik: (): alapváltozat (lejegyzés), (1)-(3): 1-3. javítás, kiegészítés) 
5. A Böszörményi szójegyzékek első példánya, (az első oldal tetején a Zsivány Szók, a második lap versóján a ZSIVÁNY Nelv címet viselö) I. Böszörményi szójegyzék (BöszSzj.I.) egy 1775. február 7-én Nánáson indult és a Hajdúkerület bíróságán Böszörményben 1776. május 29-i dátummal lezárt iratcsomóban található különböző (javarészt böszörményi, továbbá nánási, miskolci, debreceni, nagykállói és tiszalúci keltezésű) jegyzőkönyvek társaságában a Hajdú-Bihar Megyei Levéltár Hajdúböszörményi Fióklevéltárában. ${ }^{23} \mathrm{Az}$ akkor még Debrecenben őrzött szójegyzékre NAGY SÁNDOR jogtörténész bukkant rá, és ő publikálta a Múzeumi Kurírban 1970-ben (NAGY 1970).

A szójegyzékről, amely a Czagány András, Balázs Mihály, Görög Sámuel és Csengeri István „gyanús tolvajok” ellen indított eljárás irataihoz van csatolva, NAGY SÁNDOR azt írja, hogy az említett ügy nyomozása során „beszerezték a Borsodban akasztófára ítélt Oláh András kihallgatásáról Debrecenben 1775. május 10-én készült jegyzőkönyvet is. Oláh András vallomásában több olyan kifejezés szerepelt, amelynek jelentését a kihallgatást végző nótárius nem ismerte, ezért megmagyaráztatta magának[,] és a használt kifejezés közkeletü jelentését is belefoglalta a jegyzőkönyvbe. A hajdúkerület valamelyik nótáriusa aztán ennek és nyilván több hasonló jegyzőkönyv alapján összeállított egy jegyzéket a "Zsivány nyelv«-ről, illetve »Zsivány szók«-ról és azok jelentéséről[,] és ezt a valóságos kis szótárt a Czagány András és társai ellen folyt bünügy irataihoz csatolta" (NAGY 1970: 34).

NAGY SÁNDOR megállapításait korántsem vehetjük készpénznek, az iratok között nem találtam olyan adatokra, amelyek megerősítenék a szójegyzék készülésének körülményeiről szóló, egyéb vonatkozásban is pontosításra szoruló kijelentéseit. Oláh András vallomása kapcsán például semmi sem utal arra, hogy Debrecenben készült volna, ${ }^{24}$ sőt egészen bizonyos, hogy Miskolcon jegyezték $1 \mathrm{e},{ }^{25}$ hiszen Oláh András és társai ügyét ott tárgyalták, Oláh is egyike volt annak a négy kivégzett vásári tolvajnak, akiknek ügyiratai között őrződik a MiskSzj., amit épp a halálos ítéletet tartalmazó irat utolsó lapjának hátoldalára jegyzett fel a bíróság döntését írásba foglaló nótárius. Ez a Borsodban elítélt négy zsivány egyébként, akikről 1775. május 9-én Miskolcon kimondták, hogy „életeknek meg jobbitásahoz már semmi Reménség nem lévén Sóváry Joseff ugyan, Oláh András, és Szabó Miska akasztó fára, Varga Ersok pedig fővételre Szententiaz-

${ }^{23}$ MNL HBML HbFl IV. A. 505/e. 16. d., 1776. № 14., 17r-18v oldal.

${ }^{24}$ MNL HBML HbFl IV. A. 505/e. 16. d., 1776. № 14., 19-20. oldal.

${ }^{25}$ A miskolci keletkezést bizonyítja az egyik jegyzőkönyvi kérdés is: „A` Bundással itt Miskólczon hogyloptad el Szabó Pál pénzét” (MNL HBML HbFl IV. A. 505/e. 16. d., 1776. № 14., 20r). 
tatnak", ${ }^{26}$ mind Czagány András (alias Konyás) bandájához tartoztak, Varga Erzsók Czagánynak élettársa (nem hites felesége: cafká-ja) is volt. ${ }^{27}$

Mindezek alapján joggal feltételezhetnénk, hogy egyéb iratok mellett a MiskSzj. egy másolata is elkerült Böszörménybe, azonban ennek semmi nyoma nincs, sőt terjedelme és szókészlete alapján inkább az EgriSzj. valamelyik (esetleg a most ismertekkel nem is megegyezö) változata szolgálhatott mintául a böszörményi szójegyzéknek, amelynek összeállítására az is sarkallhatta akár Jablonczay Petes Jánost (aki ekkoriban a Hajdúkerület főjegyzője, majd később 1790-1809 között fökapitánya volt), akár egy ismeretlen munkatársát, hogy a Miskolcról és Egerböl ${ }^{28}$ megküldött iratokban rendre találkozhattak a zsiványnyelvet firtató kérdésekkel.

NAGY SÁNDOR kijelentésével ellentétben arra sem találni bizonyítékot a 61 számozott lapnyi böszörményi anyagban, hogy a jegyző megmagyaráztatta volna a zsiványszavakat. Mindössze arról értesülünk egy Debrecenben található (és másolatban Szügyre is megküldött) iratból, hogy Czagány András ismerte a szójegyzéket, és mintegy jóváhagyólag megerősítette a benne lévő szavak hitelességét, amikor 1776. június 5-én így nyilatkozott: „a’ magyar ZSiványokat, a' nyelveken lehet meg esmérni, a pedig a' nyelvek, a melly itt elöttem el olvastatott". ${ }^{29}$ Azt viszont, hogy ezt a böszörményi szójegyzéket miként, kitől gyüjtötték, nem tudjuk. Az mindenesetre tény, hogy az iratcsomóban (a szójegyzéken kívül) Böszörményben feljegyzett argószavak nincsenek, egyedül a Miskolcról megküldött vallomásokban találhatók zsiványnyelvi adatok, ${ }^{30}$ de azok közt olyan

${ }^{26}$ MNL NML IV. 13. 12. d., Fasc. XLV. 36/1777, № 8., 11. oldal.

${ }^{27}$ Varga Erzsók azt mondja vallomásában, hogy „Konyástul a Ki Boszormenyben fogva van Fattyat vetettem váradon” (MNL HBML HbFl IV. A. 505/e. 16. d., 1776. № 14., 23r).

${ }^{28}$ A BöszSzj.I.-et tartalmazó iratok között Egerből származók nincsenek, ellenben az egri per anyagában fellelhető egy Debrecenböl postázott levél (MNL HML XII-3/b. 15. d., e/1. cs.). Bizonyára azért kértek az egriek Debrecenből információt, mert az egyik vádlott, Somogyi, avagy Veszprémi Pista épp Debrecenben és környékén keveredett a Böszörményben (és Miskolcon) vád alá helyezett vásári tolvajok és társaik közé, és adta fejét zsiványságra. Bár Egerben készült dokumentumokat Böszörményben nem találunk, mégis több jel mutat arra, hogy az egri és a böszörményi bíróság között kölcsönös volt az irattovábbítás, és vélhetőleg az Egri szójegyzékek valamelyik példányának egy ismeretlen másolata is elkerült Böszörménybe, ahol alapjául szolgált az ott készülő szójegyzéknek, például úgy, hogy szóanyagát a Böszörményben fogva tartott vásári tolvajoktól kikérdezve gyüjtötték össze a BöszSzj.I.-et. Az Eger $\rightarrow$ Böszörmény irányt valószínüsíti egy másolási hibának tünő alak a böszörményi szavak között (vö. EgriSzj. szlepicska $\rightarrow$ BöszSzj. szlepriska) és néhány olyan szó (kajzer, tiszttartó), amelyek az egri iratokból magyarázhatók meg. (Ez utóbbiakra lásd KIs 2020: 279-280.)

${ }^{29}$ HBML IV. A. 1018/d. 2. cs.

${ }^{30}$ „A' Gyóltsot Putzinak, a pénzt Leves[ne]k, a' mentet Palinak, a' nadrágot fel huzó, a' csizmat fel rántonak, a' Sebbe valo órat tsengetjünek, a' szürt, gubát fel vevó a' sűveget, kalapot fel tevőnek hijják a' hust szalonnát, sodort, [olvashatatlan]. Az Aszszonyok Szokták mondani, tsak csapták” (MNL HBML HbFl IV. A. 505/e. 16. d., 1776. № 14, 19v), „,mikor en oda érkeztem 
szavak is kerülnek, amelyek a Böszörményi szójegyzékben (a miskolci vagy az egri szójegyzékekkel ellentétben) nem szerepelnek (bak, bali, puci), azaz nem ezeknek a jelentését akarták a hivatalos személyek megfejteni. ${ }^{3}$

A BöszSzj.I.-ről tehát csak gyanítjuk, hogy felhasználtak hozzá korábban máshol összeállított szójegyzéket, de nem tudjuk pontosan, miként és kitől gyüjtötték az anyagát, sőt még elkészítésének éve is bizonytalan, ugyanis a Böszörményben elítélt vásári tolvajok ellen folytatott per 1775-ben indult (Czagány letartóztatása már 1775 februárjában megtörtént Nánáson), úgyhogy ez alapján nem zárható ki, hogy a BöszSzj.I. első (javítások, kiegészítések előtti) változatát akár 1775-ösnek tekintsük. Mindazonáltal a címoldalán látható feljegyzés szerint (fotóját lásd VARJASI 2018: 112) 1776-ban iktatták az iratcsomóhoz, ezért célszerü továbbra is 1776-ban keletkezettként kezelnünk ezt a szlengemlékünket, pontosabb időpontnak pedig a (Czagányra nézve halálos ítélettel végződött) pert lezáró 1776. május 29-i dátumot tekinthetjük.

Az 1782-ben országszerte szétküldött BöszSzj.II.-et (ami a BöszSzj.I. másolata) Jablonczay Petes János nevéhez szokás kötni, aki a Hajdúkerület föjegyzőjeként aláírója volt a Helytartótanácshoz felküldött szójegyzéknek, melynek szövegét is teljes egészében ő jegyezte le. Azt azonban, hogy Jablonczaynak valójában mennyi köze volt a Böszörményi szójegyzék elkészítéséhez, nem tudhatjuk. A BöszSzj.I. nincs aláírva, lejegyzőjét nem ismerjük, pusztán azt tudjuk, hogy ez a személy nem azonos a Helytartótanácshoz küldött példány leírójával, azaz Jablonczay Petes Jánossal: más a helyesírása, más a betűformázása, jól láthatóan eltér Jablonczay kézírásának máshonnan ismert duktusától, azaz az biztosan kijelenthetö, hogy a BöszSzj.I.-et nem Jablonczay Petes János vetette papírra.

6.1. A BöszSzj.I. egy félbehajtott ív három oldalára van jegyezve, a negyedik (hátsó) oldal hosszában összehajtva a szójegyzék külső címlapjaként funkcionál. A szójegyzék a szavak fölé írott „Zsivány Szók” címet nem számolva 78 sorból áll, ez azonban a javítások és betoldások miatt 90 adatot és ugyanennyi szótári egységet jelent. A módosítások következtében több alakváltozattal talál-

már neki akkor vólt pénze, akkor dítsekedett hogy tud ő Levest szerezni” (uo. 20r). „a’ Rásárt [0: Vásárt] Kuksi az embert bakk az arany pénzt gagyi neven hivjak” (uo.).

${ }^{31}$ TÖRÖK GÁBOR vetette fel, hogy a Böszörményi szójegyzéknek esetleg a MiskSzj. szolgált alapjául: „Ugyanebben az csomóban találtam egy 1776. június 5-i dátumú ügyiratnak a másolatát, melynek eredetije »Per Joannem Jablonczay District ord Notār« íratott. Ebből kiderül, hogy J a b 1 o n c z a y már 1776-ban ismert egy tolvajnyelvi szójegyzéket, mert hiszen az iratban »Czagány alias Konyás András« így vall: »a’ Magyar Zsiványokat a nyelveken lehet meg esmérni, a’ pedig a' nyelvek a mely itt elöttem el olvastatott...« — Talán nem merész feltevés, ha ez a felolvasott szójegyzék az általam közöltnek valamilyen másolata, s JABLONCZAY számára forrásul szolgált későbbi szójegyzéke összeállításakor.” (TÖRÖK 1957: 273-274). TÖRÖKnek — aki az 1776-os BöszSzj.I.-ről 1957-ben még nem tudhatott, csak a szójegyzék 1782-es másolatát ismerte — ez a feltevése téves: Czagány előtt nem a Miskolcon összeállított glosszáriumot olvasták fel, hanem a Böszörményben készült BöszSzj.I.-et. 
kozunk a szójegyzékben: Perge > Pergö, Meg ruházták > Meg ruhizták, Puczi$k a>$ Pucziha, Poszterom $>$ Poszteriom, Kasznya $>$ KaSnya, Szlepriska $>$ Szlep$r$ [???]ka, Szingula $>$ Szingyula, Plede $>$ Plédez, valamint Kis viz és Nagy viz. Ha ezeket a változatokat egy-egy lexémaként számoljuk, akkor 81, ha a Letergeng > Lebernyeg javítás eredményeként létrejött párt is egynek vesszük, 80 szótári egység található a BöszSzj.I.-ben.

6.2. A szójegyzékben legalább három kéz írását láthatjuk. Az 1. kéz készítette az utolsó két szópár kivételével a szójegyzéket (néhány javítást is tett rögtön a lejegyzés során), a 2. kéz az utolsó előtti szópárt írta be (további átírások, javítások valószínüleg nem köthetők hozzá), a 3. kéz néhány szót írt be a szójegyzékbe az egyes szavak után vagy fölé, illetve lehúzott és átírással is javított néhány helyen. Valószínüleg tỏle származik a pótlólag betoldott utolsó szópár is.

Az első kéz (BöszSzj.I. $\left.{ }^{\odot}\right) 76$ sort, benne 76 adatot jegyzett le, ez a szójegyzék eredeti változata. Az első kéz vélhetőleg néhány ponton már a lejegyzés során kiigazította a szöveget, összesen három javítást kapcsolhatunk hozzá (a 13, 29 és 72 számmal jelzett sorokban), de ezek a módosítások a lexémák számán nem változtatnak. A szójegyzéknek ez az első változata (ám korántsem biztos, hogy ez a példány) volt az, amelyikről a BöszSzj.II-1.-et másolták. Ezt abból tudhatjuk, hogy az első kéz végezte javítások — szemben a későbbi módosításokkal — belekerültek az 1782-es második példányba.

A második kézhez (BöszSzj.I. ${ }^{\circledR}$ ) egy új adat (77) beírását kapcsolhatjuk, ezáltal a szójegyzék terjedelme 77 sorra és 77 adatra nőtt.

A legtöbb módosítást a harmadik kéz végezte a szójegyzéken (BöszSzj.I. (2). Javításainak idejét nem tudjuk. Mivel a harmadik kéz által bejegyzett változtatások, új adatok nem kerültek bele az 1782-ben másolt példányba, akár azt is feltételezhetnénk, hogy ezek 1782 után készültek, azonban ennek különösebb realitása nincs, hiszen a szójegyzék az 1775-1776-ban zajlott per anyagában található, ezért azt valószínúsíthetjük, hogy a módosítások is ekkor, nem sokkal az alapváltozat lejegyzése után kerültek a szövegbe, a javításoknak pedig az 1782-es változatban azért nincs nyomuk, mert nem ezt a példányt használták a másoláshoz.

A harmadik kéz — az eredetileg beírt zsiványszó meghagyása mellett — egy szinonimát (61b), illetve a szöveg végére további egy új adatot (78) jegyzett be, egy helyen pedig (47) a jelentésmegadást egészítette ki, így nyerte el a szójegyzék a végső 78 sornyi és 79 adatnyi terjedelmét, azonban a korábbi állapothoz képest további új lexémákat is tartalmaz, ugyanis a harmadik kéz kilenc esetben javítással módosította az eredeti alakot $(17 \mathrm{a} \rightarrow 17 \mathrm{~b}, 23 \mathrm{a} \rightarrow 23 \mathrm{~b}, 25 \mathrm{a} \rightarrow 25 \mathrm{~b}, 50 \mathrm{a} \rightarrow$ $50 \mathrm{~b}, 51 \mathrm{a} \rightarrow 51 \mathrm{~b}, 54 \mathrm{a} \rightarrow 54 \mathrm{~b}, 57 \mathrm{a} \rightarrow 57 \mathrm{~b}, 70 \mathrm{a} \rightarrow 70 \mathrm{~b}, 71 \mathrm{a} \rightarrow 71 \mathrm{~b}$ ), két ízben pedig törölte a korábbi zsiványszót, és helyükre újat írt be $(45 \mathrm{a} \rightarrow 45 \mathrm{~b}, 55 \mathrm{a} \rightarrow 55 \mathrm{~b})$.

A módosított szavak eredeti és új alakjait, továbbá az újonnan beírt szavakat összeszámlálva kapjuk meg a BöszSzj.I. 78 sorában a 90 adatot és az alakváltozatok egybe vagy külön számításától függően a 80-90 szótári egységet. 
6.3. A BöszSzj.I. az utólagos beszúrásoktól eltekintve gondos, jól olvasható kézírással készült, helyesírása megfelel a 18. század második felében használatosnak. Átírásában nehézséget néhány szókezdő $a, e, g$ és $v$ betü kis- vagy nagybetü voltának megállapítása okozott, ugyanis ezek szó eleji helyzetben kisbetủ alakú, de nagybetủ magasságú (vagy legalábbis a kisbetüknél magasabb) betükkel is vannak jelölve. Mivel a szójegyzékben a zsiványnyelvi kifejezések és a jelentésmegadások első szavai következetessen nagy kezdőbetűvel íródtak (továbbá a főneveket is gyakran így írta a lejegyző helyzetüktől függetlenül), ezeket a szókezdő „,nagy kisbetüket” nagybetűvel írtam át. Így tett egyébként a szójegyzék 1782-es másolója, Jablonczay Petes János is. (Mivel eljárásom esetleg vitatható, lábjegyzetben megjelöltem ezeket a helyeket.)

Megemlíthetők még a szójegyzék $k$ betủi is, bár átírásuk problémát nem jelentett. A $k$-nak három föbb alakváltozata fordul elő a szövegben: egy nagy $K$ és kétféle kis $k$. Ez utóbbiak esetében a szokásos kisbetü forma mellett használatos a nagy $K$-ra emlékeztető kisbetü is. Ennek azonosítása nem okozott gondot, ez a nagy $K$ alakú kisbetü jól felismerhetően megkülönböztethető a nagybetü $K$-któl, amelyeknek szárán egy hurok látható az alapvonalnál.

A magánhangzók írása kapcsán megemlíthetjük, hogy a lejegyző a korabeli gyakorlatnak megfelelően azonos betüvel írva nem különböztette meg a nagy $I-\mathrm{t}$ és a $J$-t. Én ezt a betüt a hangértéktől függően $I$-vel vagy $J$-vel írtam át abban a két szóban, amelyekben előfordul (Idem, Jordán). Említést érdemel még, hogy a szójegyzék lejegyzője többnyire nem tett különbséget az $\ddot{o}$ és az $\ddot{o}$, illetve az $\ddot{u}$ és az $\ddot{u}$ között, ezeket egységesen $\ddot{o}$-vel, illetve $\ddot{u}$-vel írta, azonban két-két esetben — mind a négy helyen hosszú magánhangzót jelölve — $\ddot{o}$-t, illetve $\ddot{u}$-t találunk. Az utolsó elötti sorban álló zsiványnyelvi szó (Dánkūrti) második magánhangzóját $\ddot{u}$-ként azonosítottam. Ennek okairól a 67. lábjegyzetben írok a 208. oldalon.

6.4. A szövegek lejegyzésével kapcsolatosan el kell mondanom, hogy bizonyos észszerüségi korlátok között törekedtem a betük paleográfiai változatainak visszaadására is. Ugyan ezeknek a betüknek a használatát a szójegyzék idézésekor feleslegesnek tartom, azonban épp a Böszörményi szójegyzékek második példányában fordul elő egy olyan másolási hiba (erről lásd a 211. oldalon írottakat), amit egy betủ egyik paleográfiai variánsának téves olvasása magyaráz meg, ezért szükségesnek látom a szövegközlésben az érintett betűváltozatokat elkülöníteni (3, з $\left.=z, \beta=s z, \int=s, \partial=d\right)$.

A szójegyzék átírásában meghagytam a rövidítéseket, feloldásukat lábjegyzetben adom meg. A felülírással javított helyeken a javító szándéka szerinti szót közlöm (félkövérrel kiemelve az átírt betüket és szögletes zárójelben álló kérdőjelekkel jelölve az olvashatatlan betüket), azonban — amennyiben és amennyire olvasható - lábjegyzetben megadom az eredeti szót is. A fentebb felsoroltakon kívül minden további megjegyzés is a lábjegyzetekben található. 
7. Az I. Böszörményi szójegyzék szövege betühü átírásban a következő:

[17. recto]

\section{Zsivány Szók.}

1. Fejes $, \quad, \quad, \quad$, Tißt Úr.

2. Kutya , " " \#ajdú.

3. Tißtartó „ „ " Második ßemély, a’ Fö ZSiványokk ${ }^{32}$

4. Rikkantó , " "Káça

5. Sógor " " , Német.

6. Ördög , " , " Lakat.

7. Fazék, , "Fély.

8. Lobogo , , , Keßkenö.

9. Topánka , - Bor, Pálinka.

10. Meg topánkáfodott = Meg réßegedett.

11. Füftölö " , - Pipa.

12. Szür hordó. „, „Kondás.

13. Gagyi ${ }^{33}, \quad, \quad$, Arany.

14. Nagy Viz. ${ }^{34}$ " "Sokaság a' Váfárb. ${ }^{35}$

15. Kis Viz. ${ }^{36} \quad$ " Kevés ember a Vásárban

16. ZSivány " "Tolvaj.

17. Pergo $\boldsymbol{0}^{37}, \quad, \quad$ Kocji.

18. Leves. „ „ " Pénz, Ezüft. ${ }^{38}$

19. Komnyik , " - Or Gazda. ${ }^{39}$

20. Rút ember „, „Hóhér.

21. Mefter " " Idem ${ }^{40}$

${ }^{32}=$ ZSiványok közt

${ }^{33}$ A lejegyző 1. kéz eredetileg Gaggi-t írt, amit valószínűleg már ugyanő Gagyi-ra javított.

${ }^{34}$ A szókezdő $v$-t mérete miatt (és mivel egy főnév első betüje) nagy $V$-vel írom át, bár alakja miatt kisbetünek is tekinthetnénk.

${ }^{35}=$ Váfárban

${ }^{36}$ A szókezdő $v$-t mérete miatt (és mivel egy fönév első betűje) nagy $V$-vel írom át, bár alakja miatt kisbetünek is tekinthetnénk.

${ }^{37}$ A lejegyző 1. kéz Perge-t írt, a javító 3. kéz módosította Pergö-re.

${ }^{38}$ A szókezdő $e$-t mérete miatt (és mivel egy főnév első betüje) nagy $E$-vel írom át, bár alakja miatt kisbetünek is tekinthetnénk.

${ }^{39}$ A szókezdő $g$-t mérete miatt (és mivel egy főnév első betűje) nagy $G$-vel írom át, bár alakja miatt kisbetünek is tekinthetnénk.

${ }^{40}$ Latin idem 'ugyanaz', azaz a Mefter szó jelentése a felette írott Rút ember-ével megegyezően: Hóhér. 
22. Kanaforia,

23. Meg ruhizták. ${ }^{41}$

24. Ruhi

25. Pucziha" ${ }^{42 " ~} "$

26. Jordán ,

27. Czafka

28. Balék

29. Kozákolni ${ }^{44} "$,
„Akaßtó fa.

" Meg verték, meg c fapták.

„ Csapás

"Ruha.

"ZSidó.

„Kurva.

- $A z^{43}$ Ura.

„Az Embereket ${ }^{45}$ a Vásárb ${ }^{46}$ ö zve ßoritani.

[17. verso]

30. Nyalavi. „ , „ Az Újj ZSivanyok közt leg jobb ZSivány

31. Szußogo. " , " Dißnó.

32. Kuksi „ , , , Vásár.

33. Czoff. " " , " Forént.

34. Vágván, , , , , Bicfak.

35. Czoltovájj , , , , Fizess.

36. Csácsogó „, , , , Kutya.

37. Honterozd , , , , Tagadd.

38. Nehaduvaj ", , , Ne kiálcsd ki.

39. Parás " " , " , Pénz ZSebb ${ }^{48}$ Erßény nélkül

40. Kigyó a' derekán = Tüßö Pénz. ${ }^{49}$

41. Paribó , , , Mente.

42. Gyertyázz " " ” " Vigyázz. ${ }^{50}$

43. Feltévő , " , - Kalap.

${ }^{41}$ A lejegyző 1. kéz Meg ruházták-ot írt, a 3. kéz ráírással Meg ruhizták-ra javította.

${ }^{42}$ A lejegyző 1. kéz Puczika-nak írta, majd a javító 3. kéz a $k$ betüt felülírva Pucziha-ra módosította. A javító a nagy $K$ formájú betủ sor fölé nyúló karját három vonallal lehúzta.

${ }^{43}$ A szókezdő $a$-t mérete miatt (és mivel a jelentésmegadás első betűje) nagy $A$-val írom át, bár alakja miatt kisbetünek is tekinthetnénk.

${ }^{44}$ A lejegyző 1 . kéz eredetileg Kezákolni-t írt, majd ráírással Kozákolni-ra javította.

${ }^{45}$ A szókezdő $e$-t mérete miatt (és mivel egy fönév első betủje) nagy $E$-vel írom át, bár alakja miatt kisbetünek is tekinthetnénk.

${ }^{46}=$ Vásárban

${ }^{47}$ Ezt a lap aljára írott és díszítő aláhúzással ellátott, a következő lap első szavát előjelző nyalavi szót a javításokat végző 3. kéz írta be.

${ }^{48}=$ ZSebben

${ }^{49}$ A szókezdő $p$-t mérete miatt (és mivel egy főnév első betűje) nagy $P$-vel írom át, bár amiatt, hogy szára az alapvonal alá nyúlik, kisbetünek is tekinthetnénk. A $p$ efféle írása egyébként egyedi betüforma a szövegben, sem a szó belsejében és végén írott $p$-kkel, sem a szavak első betüiként előforduló $P$-kkel nem azonos.

${ }^{50}$ A szókezdő $v$-t mérete miatt (és mivel egy főnév első betűje) nagy $V$-vel írom át, bár alakja miatt kisbetünek is tekinthetnénk. 
44. Felrántó " , , , Csizma

Fel huzó ${ }^{51}$

45. Lábra valé,” „Nadrág.

46. Rajzolni , , , , Lopni.

47. Kapkodás ” " "Szür, dolmány. Kankó. ${ }^{52}$

48. Pozdorja. " " "Gatya, Gyólcs, ${ }^{53}$ Váßon. ${ }^{54}$

49. Csengettyü " , \# ZSebbe való Óra.

50. Poßteriom ${ }^{55}, \quad$, "Tömlöcz.

51. KaSnya ${ }^{56}$, " "Szoknya.

52. Füles " " " Ló.

53. Buga " " , Ökör.

54. Lebernyeg ${ }^{57}, ", \quad$ "Köpönyeg.

55. Szörös Gyapjas ${ }^{58}$ ”, , Bunda.

56. Kopor 0 o. ” " Láda.

57. Szlepr[???]ka ${ }^{59}$, , - Katona

58. Olvajó. " „ Bilincs.

${ }^{51}$ Ezt a szót az alatta lévő szó lehúzása után a 3. kéz írta be a sor fölé, azaz a javító szerint Lábra való helyett Fel huzó a Nadrág zsiványnyelvi elnevezése.

${ }^{52}$ A Kankó-t a 3. kéz írta be utólag a jelentésmegadást lezáró pont után.

${ }^{53}$ A gyólcs szó első betűjét mérete miatt (és mivel egy főnév első betűje) nagy $G y$-vel írom át, bár alakja miatt a $g$-t kisbetünek is tekinthetnénk.

${ }^{54}$ A szókezdő $v$-t mérete miatt (és mivel egy fönév első betủje) nagy $V$-vel írom át, bár alakja miatt kisbetünek is tekinthetnénk.

${ }^{55} \mathrm{Az} 1$. kéz eredetileg Poßterom-ot írt, a szó utolsó két betüjét átírva (az $m$-et már a sorvezető első macskakörömre betoldva) valószínűleg a 3. kéz javította Poßteriom-ra.

${ }^{56}$ Eredetileg Kaßnya volt. Az átírással javított rész nehezen olvasható, valószínüleg KaSnyara módosította a 3. kéz. A kis $s$ helyetti nagy $S$ használatát azzal magyarázhatjuk, hogy a nagybetüvel az eredeti $\beta$-et akarta elfedni a javító. NAGY SÁNDOR szövegközlésében Kacsnya-ként szerepel a szó (1970: 35), de ez a KacSnya olvasat meglehetősen valószínütlen, a még felvethető Kacnya (esetleg Kacznya) pedig teljességgel kizárható, miután a 3 egyáltalán nem, a $c$ pedig csak a $c s-\mathrm{k}-$ ben és a $c z$-kben fordul elő. (Az $\beta$ felülírására használt, $c$-re emlékezető alsó résszel írott $S$ egyébként kezdőbetüként több helyen is előfordul a szövegben.)

${ }^{57}$ A lejegyző 1. kéz eredetileg Letergeng-et írt, a 3. kéz felülírással javította Lebernyeg-re.

${ }^{58}$ A Gyapjas szót kisebb betűkkel a 3. kéz írta a sorvezető macskakörmökre, a Szörös lehúzása is töle származik.

${ }^{59}$ Az 1. kéz által lejegyzett szó a Szleprifka volt (ez szerepel Szlepriska-ként a BöszSzj.II.-ben is). A 3. kéz ráírása miatt az $r$ és a $k$ közötti rész olvasata bizonytalan, ezért a javító szándékát nem lehet megállapítani. Az $\int$ betủ elött két satírozás között mintha egy $c$ lenne kivehető, az $\int$ betü után pedig talán egy $h$ látszik, viszont egy Szleprcfhka olvasat fonotaktikai okokból is teljesen elképzelhetetlen. A szó etimológialag jól magyarázható (vö. GREGOR 1972: 169) és az EgriSzj.-ből is ismert alakja a szlepicska, ez alapján leginkább egy Szlepricfka-ra vagy egy Szlepicfka-ra történő javítás szándékát feltételezhetnénk, de erre semmilyen bizonyítékunk nincs.

${ }^{60}$ Ezt a lap aljára írott és díszítő aláhúzással ellátott, a következő lap első szavát előjelző Piarifta szót a javításokat végző 3 . kéz írta be. 


\section{[18. recto]}

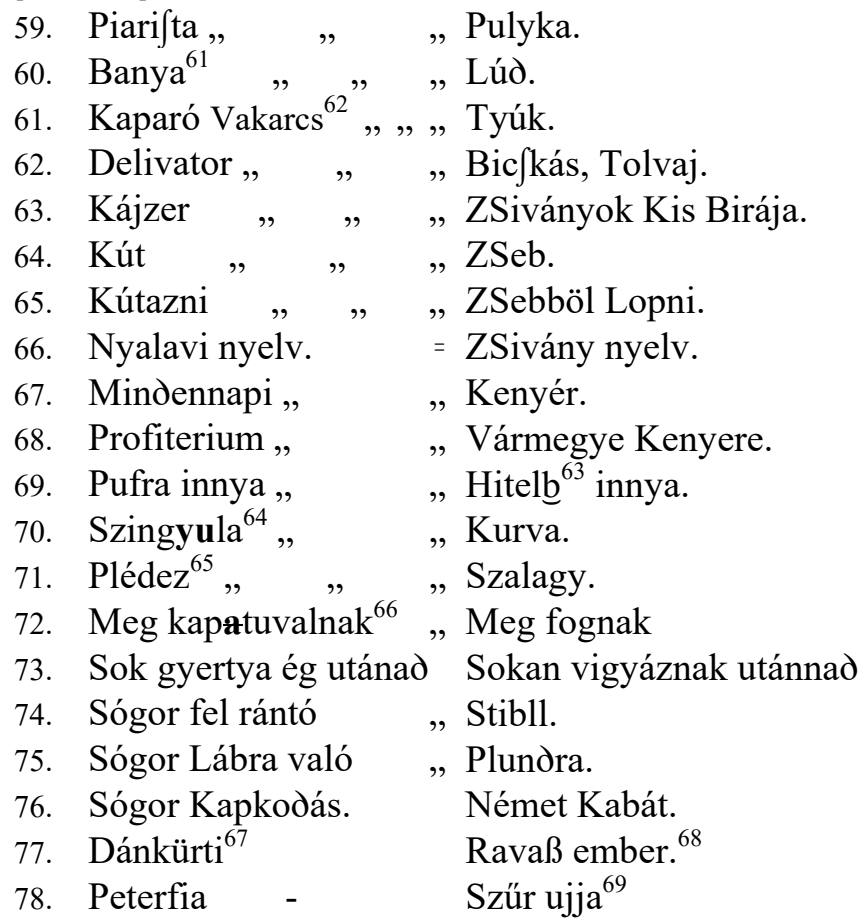

${ }^{61}$ Az első $a$ fölött egy a szokásos ékezetnél jóval hosszabb, feltehetőleg nem ékezetnek szánt vonás látható. A tinta színe alapján biztosra vehető, hogy az 1. kéz ejtette — valószínűleg véletlenül - ezt a vonást. A szót NAGY SÁNDOR is Banya-nak olvasta (1970: 35), és banya-ként szerepel az EgriSzj.-ben is.

${ }^{62}$ A Kaparó utáni nehezen olvasható Vakarcs szót (a Tyúk egy másik zsiványnyelvi megnevezését) utólag írta be a sorvezető macskakörmökre a javításokat, kiegészítéseket végző 3. kéz.

${ }^{63}=$ Hitelbe

${ }^{64}$ Eredetileg Szingula volt, valószínűleg a 3. kéz javította Szingyula-ra néhány vonallal módosítva a betüket.

${ }^{65}$ Eredetileg Plede volt, az első $e$ betűhöz a szokásosnál közelebb eső, sőt ahhoz hozzáérő ékezetet és a sorvezető első macskakörömre ráírt szóvégi z-t a 3. kéz toldotta be.

${ }^{66}$ A $p$ betű utáni $a$-t valószínüleg már a lejegyző 1. kéz lehúzta, azaz szándékai szerint a szó: Meg kaptuvalnak.

${ }^{67}$ A szó második magánhangzójának $\ddot{u}$-ként való azonosítása nem egyértelmű, ugyanis az ékezetnek tekintethető két vízszintes vonás egymástól viszonylag távol helyezkedik el, az egyik az $u$, a másik pedig a bizonytalan olvasatú $r$ és a $t$ fölött (nagyjából ilyen formán: Dánkūrti). Az érintett betű $u$-nek olvasása ellen az szól, hogy a szó első magánhangzóján, az á-n látható, hosszúságot jelölö ékezet sokkal hosszabb, és dőlt vonással van írva.

${ }^{68}$ Ez az utolsó előtti sorba beírt szópár a szójegyzékben máshol nem azonosítható 2 . kéz bejegyzése lehet.

${ }^{69}$ Az utolsó sor (figyelembe véve például a szövegbe beírt javítások betüinek vonalvezetését és a vonalak vastagságát) valószínűleg a javításokat, betoldásokat végző 3. kéztől származik, bár nem elképzelhetetlen az sem, hogy az eredeti lejegyzést készítő 1 . vagy esetleg egy 4 . kéz beírása. 
8.1.1. Az I. Böszörményi szójegyzék egy-egy részéről fotók a következő publikációkban találhatók: KIS 2013: 13, VARJASI 2015: 169, 2016: 7, 2018 : 112-113. (VARJASI írásainak az BöszSzj.I.-re vonatkozó részei alapvetően — és többnyire hivatkozások nélkül — KIS TAMÁS 2013-as cikkéből származnak.)

8.1.2. Az I. Böszörményi szójegyzék teljes fakszimiléje ezen a helyen érhető el: http://mnytud.arts.unideb.hu/szleng/regi/zsivanyny_1776_szines.pdf.

8.2. Az I. Böszörményi szójegyzék szövegét az eddigiekben az alábbi publikációkban tették közzé: NAGY 1970, KIS 2002: 69-70.

9. A II. Böszörményi szójegyzékek (BöszSzj.II.) közé a BöszSzj.I. 1782ben a Helytartótanácshoz elküldött kéziratos másolata és ennek a Helytartótanács által kinyomtatott változata tartozik.

Ez a szójegyzék szintén egy vásári tolvajok elleni büntető eljárásnak köszönhető: a Czagány-féle banda tagjainak 1775-1776-os bebörtönzése és a fökolomposok kivégzése után az 1780-as évek elején Böszörmény környékén újabb vásári tolvajokat fogtak el. Perük 1782-ben zajlott a Hajdúkerület székhelyén. Mivel ezek közül a bünözők közül többen kapcsolatban álltak a pár évvel azelőtti perekből ismert zsiványokkal, ${ }^{70}$ a törvényszéken előkeresték és bizonynyal felhasználták a korábbi perek iratait is. Így kerülhetett át az 1776-ban készült Zsivány Szók címet viselő BöszSzj.I. másolata az 1782-es per dokumentumai közé.

Ez utóbbi pernek az anyaga a hajdúböszörményi levéltárban csak töredékesen maradt fenn, ${ }^{71}$ és ezek között az iratok között a nevezetes zsiványnyelvi szójegyzék nem található meg. A Jablonczay Petes János főjegyző által aláírt szójegyzék egy hiteles példánya azonban az Országos Levéltárban megőrződött, ugyanis Mária Terézia „1756-ban elrendelte, hogy a halálbüntetést kiszabó ítéleteket kihirdetésük elött az összes iratokkal együtt a Helytartótanács útján hozzá fel kell terjeszteni a kegyelmezési jog gyakorlását illető döntés végett” (NAGY 1990: 70). Ennek köszönhetően a Bessenyei Mihály, Reszegi János, Cséplő Sára, Bokor (Oláh) Judit és mások ellen indított pernek az ügyiratai a Helytartótanácshoz kerültek, melynek anyagában jelenleg is megtalálható a

\footnotetext{
${ }^{70}$ Bokor Judit és Czagány András kapcsolatáról például ezt vallja Cséplő Sára: „Hogy nagy baráttya' volt Bokor Judith CZagánynak, mert a' mikor már itt Böszörményben meg Sententiáztatott 's imádkoztatott CZagány, Bokor Judithot magához hivatta, 's egész nap is ott volt vélle a' Házban Söt azt mondotta nékem Bokor Judith, hogy a' Zsivány Kis Késit is mellyel a sebeket szokták ki vagdalni, azt is CZagány Bokor Judithra' hagyta, és átaladta néki." (MNL OL C 43 Acta secundum referentes - Sauska - 1782 - Fasc. 62.). Vö. még „Tudod e' hogy Bokor Judith Zsiványkodott együtt Czagánnyal? - Azt nem tudom: mert egyebet nem hallottam tülle, hanem hogy Tanitványa volt." (uo.).
}

${ }^{71}$ MNL HBML HbFl IV. A. 505/e. 25. d. 1782. № 2. 
Hajdúböszörményben készült és onnan felküldött szójegyzék kézirata. ${ }^{72}$ Címe:

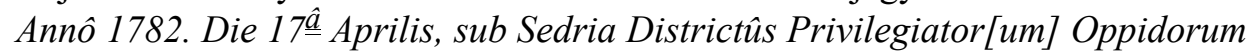
Hajdonicalium Causarum Criminalium Revisoria, in Oppido Böszörmény celebrata, Consignatio Terminorum, et Vocum, qvibus Fures Nundinales, vulgô 'Sivány, seu Vásári Tolvaj, in mutuo colloqvio, occasione patrandorum furtorum uti consveverunt, azaz: Az 1782. év április 17-én a kivételezett hajdú városok kerületi törvényszéke bűnügyi vizsgálóbizottságának ülése, melyet Böszörmény városában tartottak; azon szavak és kifejezések jegyzéke, melyet a vásári tolvajok (közönségesen 'Sivány, vagy Vásári Tolvaj) egymás közt folytatott beszélgetésein a tolvajlás végrehajtása alkalmával használni szoktak.

Ez az Országos Levéltárban örzött kéziratos példány a II-1. Böszörményi szójegyzék.

10. A II-1. Böszörményi szójegyzék (BöszSzj.II-1.) másolat, ezért ennek szókészlete nem elkészülte idejének, hanem az eredeti példányban található anyag gyüjtési évének nyelvállapotát mutatja. Mivel azonban a kettő között mindössze hat-hét esztendő eltérés van, ráadásul ugyazon tolvajbanda újabb generációjának nyelvét hivatott bemutatni, akkor is a valós, korabeli zsiványnyelvet tükrözné, ha nem ellenőrizték volna a szavakat 1782-ben, hanem csak mechanikusan lemásolják az 1776-os példányt. Az ellenőrzés azonban nem maradt el, a szójegyzéket felolvasták a zsiványok előtt (legalábbis Bessenyei Mihály elött biztosan), mint ezt az alábbi jegyzőkönyvi bejegyzés bizonyítja: „El olvastatván előtte a' Sivány Tolvajoknak Nyelvek, azokat azon módon a' mint irva Vagyon elmagyarázta." ${ }^{, 73}$

A szójegyzék mellett az 1782-es per iratai is nagyobb mennyiségben tartalmaznak zsiványnyelvi szavakat, azonban ezek egy része nem található meg a szójegyzékben, ami azt mutatja, hogy a bíróság munkatársai nem törekedtek arra, hogy a szójegyzék anyagát kiegészítsék az előkerült újabb szavakkal, bár a jegyzőkönyvekből azt is láthatjuk, hogy a törvény képviselői erősen érdeklődtek a zsiványnyelv és ennek ismerete iránt. A vallomások szövegében (a bünözőkön kívül a vallatást vezetők kérdéseiben is) gyakran találunk zsiványszavakat: „Rajzoltál é akkor valamit, kikkel, és mit?”, „Nem rajzoltam Semmit is”,74 (rajzol 'lop'), „bé mentünk mi a' Kuksi végire”,75 (kuksi 'vásár') stb. Van arra is példa, hogy magára a zsiványnyelvre kérdeztek rá. Bessenyei Mihály és a bíró között például a következő párbeszéd zajlott le: „Ugy é hogy vagyon a’ Sivány

${ }^{72}$ MNL OL C 43 - Acta secundum referentes - Sauska - 1782 - Fasc. 62.

${ }^{73}$ MNL OL C 43 - Acta secundum referentes - Sauska - 1782 - Fasc. 62.

${ }^{74}$ MNL OL C 43 - Acta secundum referentes - Sauska - 1782 - Fasc. 62.

${ }^{75}$ MNL OL C 43 - Acta secundum referentes - Sauska - 1782 - Fasc. 62. 
Tolvajoknak külőnős Nyelvek. — Vagyon valami”, „Kitől tanultad ezt a nyelvet? - Azoktól a’ Jóktól, a’ kiket elől számláltam, és szellyel az Országban.”76

Cséplő Sára vallomásában a szavak felsorolása mellett zsiványnyelvi mondatokat is találunk: „Mond el hát mit tudsz azon a’ Nyelven, és hol tanitottak? Midön Debreczenbe mentünk volna leg elöször lopni, melly Zsivány ságra Bokor Judith és Fejér Sára tanitottak, ugyan ekkor ezt mondották. Ha Zsiványokat találok ugy mondgyam csak Bezzeg vólt jó viz Nyalék pozdorját az annyit tészen, hogy sok ember volt a' Gyolcs Árulóknál lehetett lopni Gyolcsot, Nyalni, azt tészi lopni. Pozdorja Gyolcs. Jó viz, Sok ember. Lobogo Sellyem Keszkenö. Kuksi Vásár Dóka December, ${ }^{77}$ Kutya Hajdú[,] Város cselédgye. | Mikor a' Thedejen tavally meg fogtak bennünket akkor Reszegi, Fejér Sári Bokor Judith ott együtt lévén Reszegi mondotta Fejér Sárinak, Jó viz vólt most mert rajzolt Fejér Sári. Jól rajzolni, annyit tészen mint Pénzt lopni. de többet nem tudok." ${ }^{78}$

11. A BöszSzj.II-1. eredetije a BöszSzj.I.-nek az első kéz által lejegyzett (azaz a későbbi javítások előtti) változata (BöszSzj.I.๑) volt, amely 76 sorában 76 lexémát tartalmaz. A BöszSzj.I. végső változatában még további két kéz módosításai láthatók, ezért valószínüsíthetjük, hogy az 1782-es másolat alapja nem a hajdúböszörményi levéltárban jelenleg fellelhető példány, hanem annak egy esetleg másik ügyirathoz csatolt vagy valamelyik jegyzőnél ôrzött változata lehetett. Ennek a köztes példánynak a létezését egy a BöszSzj.II-1.-be íráshibával bekerült alak is alátámasztani látszik. A BöszSzj.I.-ben a fázik 'fél' ige Fazék (tkp. Fázzék) alakban, $z$-vel szerepel, a BöszSzj.II-1.-ben viszont már ezt találjuk: Fasék. Ennek a hibának a legkézenfekvőbb magyarázata az, hogy a másoló egy olyan példányt használt (a BöszSzj.I. nem ilyen), amelyikben a Fazék szóban a $z$ betü 3-vel volt írva, és ezt a 3 -t tévesztette össze az írott $s$ betű fordított $c$-re ( $($, s) emlékeztető változatával. (A 3 paleográfiai változat a BöszSzj.II-1.ben egyébként három ízben előfordul.)

Találunk további arra utaló jeleket is — akár létezett a köztes példány, amiről esetleg a BöszSzj.II-1.-et másolták, akár nem —, hogy a BöszSzj.I. Hajdúböszörményben megőrződött példánya volt a BöszSzj.II-1. végső eredetije. Ezt mutatja például a következő betütévesztés: az egri szójegyzékekből tudjuk, hogy a 'lúd' zsiványnyelvi elnevezése a banya volt. Ez a szó így szerepel a BöszSzj.I.-ben is, azonban az első $a$ betü fölött egy a szokásos ékezetnél jóval hosszabb, elég nyilvánvalóan nem ékezetnek szánt, véletlenül ejtett vonás látható. A BöszSzj.II-1.-ben a banya á-val, Bánya-nak van írva, aminek oka ez az a feletti, ékezetnek vélt vonás lehet. (A helyzetet kissé bonyolítja, hogy a

${ }^{76}$ MNL OL C 43 - Acta secundum referentes - Sauska - 1782 - Fasc. 62.

${ }^{77}$ December 'posztóval borított prémes bunda; bokáig érő, ujjatlan báránybőr bunda'.

${ }^{78}$ MNL OL C 43 - Acta secundum referentes - Sauska - 1782 - Fasc. 62., ugyanez: MNL HBML HbFl IV. A. 505/e. 25. d. 1782. № 2., 35r, 53v, 76r-76v és 135r-135v. 
BöszSzj.II-1.-ben a Bánya szón látható ékezet színe sötétebb a betükénél, és a többi ékezettől eltérő dőlése alapján valószínüsíthető, hogy utólag lett beszúrva az $a$ fölé. Ez azonban nem gyengíti az elöbbi okfejtést, ugyanis talán az történhetett, hogy a másoló először Banya-t olvasott, majd a szöveget visszanézte, és utólag úgy ítélte meg, hogy a bizonytalan olvasatú eredeti szóban inkább á van írva, ezért pótlólag kitette az ékezetet. Mivel a BöszSzj.II-1. javításai nem látszanak későbbinek az alapszöveg lejegyzésénel, ezt a ,javítást” vélhetőleg már rögtön a másolással egy időben megejtette.)

Van még egy további olyan rontott alak a BöszSzj.II-1.-ben, amit szintén a BöszSzj.I.-ből tudunk megmagyarázni, ez pedig a Kaßakolni. A BöszSzj.I.-ben ez Kozákolni-ként szerepel, amit viszont a lejegyző eredetileg Kezákolni-nak írt, majd ezt ráírással kijavította. Valószínűleg e miatt a felülírt betü miatt olvasták a szót tévesen Kaßakolni-nak.

A BöszSzj.II-1. eltér még az 1776-os előzményétől abban is, hogy terjedelme két sorral rövidebb (74 sor), mivel kimaradt belőle két ismétlődő jelentésünek ítélt szó, a 15. (Kis viz) és a 21. (Mester). A szójegyzék két szavában (banya $\rightarrow$ bánya, profiterim $\rightarrow$ profiterium) találunk javítást, ezek azonban az adatok számán (74 adat) nem változtatnak, hiszen nem másik létező zsiványnyelvi szót töröltek vagy írtak át a javításokkal, a cél pusztán a másolási hibák kiigazítása volt. (A BöszSzj.I. második és harmadik kéz által beírt módosításai, pótlásai természetesen szintén hiányoznak a BöszSzj.II.-böl.)

A BöszSzj.II-1. a BöszSzj.I.-nek a szavak sorrendjét is megtartó, pontos másolata, bár az eddig felsorolt kisebb eltéréseken túl találunk továbbiakat is, amelyek egyrészt a másoló helyesírásából adódnak (pl. az $\beta$ helyett időnként $s z$-et vagy a $c s$ helyett $t s$-t ír, az igekötőket kötőjellel kapcsolja az igéhez stb.), másrészt pedig a zsiványszavak alakján és jelentésük megadásán is változtat a szójegyzék készítője: van, ahol kiegészíti a jelentést (pl. a Rikkantó esetében Kácfa helyett Katsa, vagy Rútza), előfordul, hogy az igei alak helyett fónévi igenevet ad (pl. Meg topánkáfodott helyett: Topánkásodni), vagy egyes hosszabb szerkezeteket szónyi terjedelmü formákkal cserél fel (pl. a Kigyó a' derekán - Tüßö pénz helyett Kigyó - Tüszö) stb.

12. A BöszSzj.II-1. (azaz Jablonczay Petes János főjegyző) írásképe kifejezetten szép, gondos, helyesírása következetes. A bizonytalan helyek olvasatában sokat segít, hogy ezt a példányt használta a BöszSzj.II-2.-et szedő nyomdász is, így a nyomtatott változatból korabeli válaszokat kapunk a felvetődő kérdésekre. Ilyen kérdés lehet a BöszSzj.II-1.-ben is a nagybetüs-kisbetüs átírás egyes szavak első betüje esetében. Ugyan néhány zsiványnyelvi kifejezés és jelentésmegadás kezdőbetűjét alakja alapján kisbetünek is tekinthetnénk, elfogadva a nyomdásznak a BöszSzj.II-2.-ben alkalmazott megoldását, ezeket következetesen nagybetükkel írtam át. 
A szójegyzék ékezethasználata kapcsán megjegyzendő, hogy Jablonczay az $\ddot{o}$ és az $\ddot{o}$, illetve az $\ddot{u}$ és az $u$ között nem tett különbséget, egységesen ugyanolyan ékezettel $\breve{o}$-nak és $\breve{u}$-nak írta. Én ezeket $\ddot{o}$-vel, illetve $\ddot{u}$-vel adom vissza, miként a nyomtatott BöszSzj.II-2.-ben is így látható.

Az egyes betűk paleográfiai változatai kapcsán a $z$ érdemel említést. Ez a betü négy főbb alakváltozatban fordul elö: a 3, a 3 és a $z$ (amit gyakran a következő betük alá nyúló hosszú alsó vonallal írt a lejegyző), valamint az utóbbi két változat „keresztezése”, amikor а з alja egy olyan alsó vonalban végződik, mint amilyen a $z$-knél látható. Ezeket a „keresztezett” 3 betüket is $z$-vel jelöltem.

13. A II-1. Böszörményi szójegyzék szövege betühü átírásban a következő:

[recto]

Annô 1782. Die 17 $\underline{\underline{a ̂}}_{\text {Aprilis, sub Sedria Districtûs Privilegiator }}{ }^{79}$

Oppidorum Hajdonicalium Causarum Criminalium Revisoria, in

Oppido Böszörmény celebrata, Consignatio Terminorum, et Vocum,

qvibus Fures Nundinales, vulgô 'Sivány, seu Vásári Tolvaj,

in mutuo colloqvio, occasione patrandorum furtorum uti con= sveverunt.

Peculiares Voces Furum Nundi= Interpretatio Hungarica. nalium.

1. Fejes $-\quad-\quad-\quad-\quad$, Tiszt Úr.

2. Kútya $-{ }_{-}-{ }_{-}$, Hajdú.

3. Tißtartó $-{ }_{-}-{ }_{-} \quad$, Második Személly az feö 'Siványok közt.

4. Rikkantó - $-{ }^{-}-{ }_{-}$, Katsa, vagy Rútza.

5. Sógor $-{ }_{-}-{ }_{-}$, Német.

6. Ördög $-\ldots+\ldots$, Lakat

7. Fasék $^{80}-\ldots-\ldots$, Fély

8. Lobogó - - - $-\ldots$, Kefzkenö

9. Topánka $-{ }_{-}-{ }_{-}$, Bor, Pálinka

10. Topánkásodni,------ , Részegeskedni

11. Füstölö $-{ }_{-}-{ }_{-}$, „Pipa

12. Szür hordó $-\ldots \ldots$, Kondás

13. Gagyi $-\ldots+\ldots$, Arany

14. Nagy Viz - - - $-\ldots$, Sokaság a’ Vásárban

15. 'Sivany $-\ldots--,--$, ,Tolvaj

16. Perge $-\ldots+\ldots$, Kotsi, vagy Szekér

17. Leves $-\ldots-\ldots$, Ezüst pénz

18. Komnyik $-\ldots----$, , Orgazda

${ }^{79}=$ Privilegiatorum

${ }^{80}$ Másolási hiba a Fazék (tkp. Fázzék) helyett. Erről lásd a 211. oldalon írottakat! 
19. Rút Ember $------\ldots$, , Hóhér

20. Kanaforia $-\ldots-\ldots,-\ldots$, Akaßtófa

21. Meg = rúházni $--\ldots-\ldots,-$, Verni, vagy csapni

22. Rúhi,--------- , Csapás

23. Púczika $--_{-}-{ }_{-}$, Rúha

24. Jordán $-\ldots--,-$, , 'Sidó

25. Czaffka,,------ , Kúrva

26. Balék $-\ldots+-\ldots,--$, , Az Úra

27. Kaßakolni $--_{-}-{ }_{-}$, Öszve szoritani a' Vásárt

28. Nyalavi $-\ldots+-\ldots+-\ldots$, , Az újj 'Siványok Közt leg jobb

29. Szúßogó --------- , Disznó

30. Kúxi $------\cdots$, , Vásár

31. Czaff $----_{-}--$, , Egy forintos

32. Vágván --------- , Bitsak, vagy Penna czilús

33. Czoltovaj ------ , Fizes

34. Csatsogó -------- , Kútya

35. Hontirozd,------ , Tagadd

36. Nehadúváj $-\ldots-\ldots, \ldots$, Ki ne Kiáldoso

[verso]

37. Para'z $^{81} \quad-\quad-\quad-\quad-\quad-\quad$, Erszény nélkül pén3 a' zsebbe

38. Kigyó $-\quad-\quad-\quad-\quad-$, Tüszö

39. Paribó $-\quad-\quad-\quad-\quad-$, Mente

40. Gyertyázz $-{ }_{-}-{ }_{-}-{ }_{-}$, ,Vigyázz

41. Fel = tévö,----- , Kalap

42. Fel = rántó $--_{-}-{ }_{-}$, , Csizma

43. Lábra való $-{ }_{-}-{ }_{-}$, ,Nadrág

44. Rajzolni $--_{-}-{ }_{-}$, Lopni

45. Kapkodás $-{ }_{-}-{ }_{-}$, , Kankó

46. Pozdorja - $-{ }_{-}-{ }_{-}$, , Gyólts váßon

47. Csengettyü $-{ }_{-}-{ }_{-}$, ,Zsebbe való óra

48. Posterium $-{ }_{-}-{ }_{-}$, , Tömlötz

49. Kasznya $--_{-}-{ }_{-}$, Szoknya

50. Füles $--_{-}--_{-}$, Ló

51. Búga $--_{-}-{ }_{-}$, Ökör

52. Letergeng $---_{-}-{ }_{-}$, Köpönyeg

53. Szörös $-\quad-\quad-\quad-\quad$, Búnda

${ }^{81}$ A Para'z szóban látható ékezet formája az aposztrófok írásával mutat egyezést. A Para'z alak létrejöhetett a Para's Parázs írásmódok keveredése miatt, de az is lehetséges, hogy az a után (az $a$ ' névelő hatására) automatikusan írta az aposztófot a lejegyző (vö. a 70. lábjegyzetben: baráttya', Judithra', MNL OL C 43 - Acta secundum referentes - Sauska - 1782 - Fasc. 62.). 

54. Koporsó $-\ldots-\cdots$, Láda
55. Szlepriska $-\ldots+\cdots$, Katona
56. Olvasó $-\ldots+\ldots$, Bilints
57. Piárista $-{ }_{-} \quad-\quad-$,Púlyka
58. Bánya ${ }^{82}-\ldots+\ldots$, Lúd
59. Kaparó $-\ldots+\ldots$, Tyúk
60. Delivator $-\ldots+\ldots$, Bitskás Tolvaj
61. Kajzer $-\ldots+\ldots$,'Siványok Kis = Birája
62. Kút $-\quad \ldots \quad-\quad-\quad$,Zseb
62. Kútazni $-{ }_{-}-{ }_{-}$, „Zsebbül lopni
64. Nyalavi nyelv $-\ldots+\ldots$, Zsivány nyelv
65. Mindennapi $-\ldots \ldots$, Kenyér
66. Profiterium ${ }^{83} \ldots \ldots \ldots$, Vármegye Kenyere
67. Púffra ${ }^{84}$ innya $-\ldots, \ldots$, Hitelbe innya
68. Singula $-{ }_{-}-{ }_{-}$, ,Kúrva
69. Plede $-\ldots+\ldots$, Szaladj
70. Meg = Kaptúválnak,------ Meg = fognak
71. Gyertya ég $-\ldots \ldots$, Vigyáznak
72. Sógor fel = rántó,----- , Stibli.
73. Sógor lábra való,----- „Plúndra
74. Sógor Kapkodás,----- ,Kapút.

Per Joannem Petes Jablonczay
$m p^{85}$
District ord JurNotarium $^{86}$

14.1.1. A II-1. Böszörményi szójegyzék egy apró részletéről készült fotó a következő publikációkban található: KIS 2013: 14, VARJASI 2015: 170.

14.1.2. Az II-1. Böszörményi szójegyzék teljes fakszimiléje ezen a helyen érhető el: http://mnytud.arts.unideb.hu/szleng/regi/boszszjii1.pdf.

14.2. A II-1. Böszörményi szójegyzék szövege eddig az alábbi helyen jelent meg: KIS 2002: 71-73.

${ }^{82}$ A betűkénél sötétebb színe és a többi ékezettől eltérő dőlése alapján feltételezhető, hogy az ékezetet utólag, de még a szöveg lejegyzése folyamán írta be Jablonczay Petes János.

${ }^{83}$ Valószínủleg egy eredetileg hibásan Profiterim-nek írott szó lett átjavítva úgy, hogy a szóvégi $m$ harmadik lábára és az ebből induló betűfarokra írt rá a javító, ezáltal az $m$-et $u m$-má alakítva. A javítás akár utólag, nem a lejegyzéssel egy időben is keletkezhetett.

${ }^{84}$ A két $f f$ alsó felén húzódó $S$-szerü vastag vonallal valószínüleg a második $f$ alsó hurkát kívánta megerösíteni a javító.

${ }^{85}$ mp 's. k.' (< latin manu propria 'saját kezével').

${ }^{86}=$ Per Joannem Petes Jablonczay mp Districtus ordinarium Juratum Notarium 'Jablonczay Petes János s. k. a Kerület hites föjegyzője által'. 
15. A Böszörményi szójegyzékek harmadik változata a II-2. Böszörményi szójegyzék (BöszSzj.II-2.), ami a BöszSzj.II-1.-nek a nyomtatott verziója. Történetéről tudjuk, hogy a hajdúkerületi fellebbviteli törvényszék (Sedria causarum criminalium revisoria) Böszörményben 1782. április 17-én hozott ítéletet a hajdú városokban elfogott vásári tolvajok ügyében. Ennek a pernek az anyagához csatolták az 1776-ban készült BöszSzj.I. másolatát. A Jablonczay Petes János által másolt tolvajnyelvi szójegyzéket (BöszSzj.II-1.) a Hajdúkerület az ügy egyéb iratainak társaságában felterjesztette a Magyar Királyi Helytartótanácshoz, mely Pozsonyban 1782. május 13-án tartott ülésén 3247. sz. alatt foglalkozott vele. Miután a Helytartótanács úgy ítélte meg, hogy a zsiványnyelvi szavak révén a vásári tolvajok könnyebben felismerhetők, úgy döntött, hogy a BöszSzj.II-1.-et megküldi a vele levelezésben álló helyi hatóságoknak. „Az összes hatóságokhoz szóló körleveleket (circularia), személyleírásokat stb., nem kézzel másolták le, hanem nyomdába adták. A korrektúrát maga a kiadó, vagy segéde végezte, ő sürgette a nyomdát s gondoskodott róla, hogy a nyomtatványok gyorsan és pontosan elkészüljenek és időben rendeltetési helyükre jussanak." (EMBER 1940: 149-150). Így készült el a BöszSzj.II-2. is, amit a Helytartótanács egy körlevélhez csatolva szétküldött szerte az országban (IMPLOM 1957: 270-271). A körlevél a zsiványnyelvi szójegyzékkel kapcsolatban a következő információkat közölte:

„3247. A magyar nyelven Zsiványnak vagy Vásári Tolvajnak nevezett vásári tolvajok bizonyos kifejezéseiről, amelyeket ezek használni szoktak, és akik jó néhány éve az egész királyságban a köz és a magánosok roppant nagy kárára garázdálkodnak. Ezek közül a Kivételezett Hajdú Városokban jó néhányat elfogtak, és azok alapos vizsgálatából kiderült, hogy a tolvajok ezen veszélyes társasága megszokta, hogy hivatásszerúen rablásból él, és különösen a vásárok résztvevőit, ahol sokan szoktak összejönni, igen nagy mértékben megkárosítja, továbbá hogy e tolvajokhoz az elbocsátott katonák közül sokan csatlakoznak, és a katonai állapot védelme alatt régóta sokkal szabadabban garázdálkodnak, mint másutt. Továbbá a szigorú vizsgálatból az is kiderült, hogy az említett tolvajok az emberek becsapásának és a tolvajlások elkövetésének minél nagyobb megkönnyítésére, a célból, hogy ahová az egész Királyságban csak eljutnak, ezen elvetemült emberek saját fajtájukat felismerhessék, megszokták, hogy sajátságos kifejezéseket használjanak.

Ennélfogva fent említett uraságotokkal a Helytartótanács e szavak vagy kifejezések birtokában azokat magyar értelmezésükkel ellátva csatoltan közli, hogy az említetteket elfogják, azokat is leleplezzék, akik a vásárokon ezen kifejezéseket szokták használni, ami a legbiztosabb jele annak, hogy a tolvajok említett társaságába tartoznak. [Mindezt azért közöljük,] hogy minél biztosabban elfoghassák őket; hogy ki-ki az ilyesféle rosszakaratú emberektől óvakodhassék, és hogy azokat minél könnyebben megfigyelhessék, továbbá ugyanezen fent emlí- 
tett uraságotok saját kebelükön belül ezt a tényállást a megszokott módon közzétehessék.

A Pozsonyi Magyar Helytartótanács 1782. év május havának 13. napján hozott határozata alapján." ${ }^{, 87}$

16. Ez az 1782-ben szétküldött értesítés és a hozzá csatolt félíves nyomtatott zsiványnyelvi szójegyzék (BöszSzj.II-2.) legtöbb levéltárunkban fellelhető a Helytartótanács körlevelei között, bár arra is ismerünk példát, hogy a levéltári anyagban csak utalást találunk rá, de maga a szójegyzék már nincs meg. Veszprém vármegye közgyülése például 1782 . június 17 -én tárgyalta a körlevelet, ${ }^{88}$ azonban a körlevélhez tartozó iratanyag nem maradt fenn, így a jegyzőkönyvben (612. lap) megemlített zsiványnyelvi szójegyzék sem. ${ }^{89}$ Tudjuk, hogy Pécs Szabad Királyi Város is megkapta a körlevelet, ${ }^{90}$ de maga az irat itt sincs meg.

Mindazonáltal a BöszSzj.II-2. megőrződött példányainak száma így is meglehetősen nagy lehet. Az általam ismertek a következők:

Baranya vm.: MNL BaML IV. 1. b. (Baranya vármegye nemesi közgyülésének iratai. 296-299/1782.)

Békés vm.: MNL BéML IV. A. 1. b. 216/1782.

Bihar vm.: MNL HBML IV. 1/b. 153. doboz. (Bihar vármegye nemesi közgyülési iratai. Közgyülési iratok. 298/1782.)

Buda: BFL IV. 1002. e. (Buda város Tanácsának iratai. Helytartótanácsi rendeletek. 922/1782.)

Debrecen: MNL HBML IV. 1011/c. 23. doboz. (Debrecen város tanácsának iratai. A M. Kir. Helytartótanács rendeletei. 51/1782.)

Fejér vm.: MNL FML IV. 1. c. (Fejér vármegye nemesi közgyülésének iratai, Acta politica. Közgyülési iratok. 135/1782. sz.)

Győr: Győr Megyei Jogú Város Levéltára, jelzete: IV. A. 1056/f/25. 3612. (Helytartótanácsi rendeletek közigazgatási ügyekben)

Győr vm.: MNL GyMSMGyL IV. A. 1. c. 76. doboz. (Győr vármegye nemesi közgyülésének iratai. 371/1782.)

${ }^{87}$ A fordítást TEGYEY IMRÉnek köszönöm. A körlevél latin nyelvű szövegét IMPLOM JózSEF tette közzé (1957: 271), eredeti kézirata a helytartótanácsi levéltárban található közvetlenül a szójegyzék után (MNL OL C 43 - Acta secundum referentes - Sauska - 1782 - Fasc. 62.).

${ }^{88}$ MNL VeML IV.1.a: 107/1782. június 17.

${ }^{89}$ Ugyanez a helyzet a Somogy Megyei Levéltárban is: a nemesi közgyülési jegyzőkönyv 1782. évi kötetének 122-126. oldalán található bejegyzés a helytartótanácsi körlevéllel kapcsolatban (MNL SML IV. A. 1. b. Somogy Vármegye Nemesi Közgyülés és Albizottsága iratai. Közés kisgyülési jegyzőkönyvek. 53. kötet; 1782. július 15. kgy. 23. sz.), ugyanis a vármegye 1782. július 15-i közgyülésén 23. szám alatt foglalkozott a kérdéssel, ám az iratok közül a szójegyzék hiányzik (MNL SML IV. A. 1. a. Somogy Vármegye Nemesi Közgyülés és Albizottsága iratai. Közgyülési iratok. 100. d. 1782. július 15. kgy. 23. sz.).

${ }^{90}$ Pécs Város Levéltárának jegyzökönyvébe a 310-311. oldalon vezették be (MNL BaML IV. 1003. a. Pécs város Tanácsülési jegyzőkönyvei. 567/1782.). 
Heves vm.: MNL HML IV-1/b 133. doboz. (218/1782.)

Moson vm.: MNL GyMSMGyL ML IV. A. 502. b. 68. doboz. (Moson vármegye nemesi közgyülésének iratai. 1729/1782.)

Nógrád vm.: MNL NML IV.1/b. Fasc. A. (234/1782.)

Székesfehérvár: Városi Levéltár és Kutatóintézet, VLKI IV. A. 1002. (Székesfehérvár város Tanácsának (senatus) iratai. b. Tanácsi és törvényszéki ügyviteli iratok. Fasc. 2. 163. oldal.)

Tolna vm.: MNL TML IV. 1. b. (Tolna Vármegye Nemesi Közgyülésének iratai. Közgyűlési iratok. Fasc. 3. № 9/1782.)

17.1. A BöszSzj.II-2. szövegét a nyomdában a kéziratos BöszSzj.II-1.-röl szedték, ezért természetesen ez is 74 sorból áll, és 74 adatot tartalmaz. A két szójegyzék közötti eltérések vagy a szedő által okozott és a korrektor által észre nem vett nyomdahibák (vagy $\rightarrow$ vágy, Tagadd $\rightarrow$ Tagad, Közt $\rightarrow$ kozt, Zsivány nyelv $\rightarrow$ Zsiványs nyelv, Plundra $\rightarrow$ Plündra, Kapút $\rightarrow$ Kapót), vagy helyesírási eltérések (Szür hordó $\rightarrow$ Szürhordó, 'Sivany $\rightarrow$ Sivany, Úra $\rightarrow$ Ura, Kajzer $\rightarrow$ Kaizer, szaladj $\rightarrow$ szalagy stb.). Minden másban a két szójegyzék tökéletesen megegyezik.

17.2. BöszSzj.II-2.-nek mint nyomtatott szövegnek az olvasásával értelemszerüen nincsenek nehézségek, tipográfiai sajátosságként mindössze a ligatúrák (ct, ff, fi, fi, ft) használatát lehet megemlíteni. Az alábbi közzétételben ezeket és a régies betüformákat $(\Upsilon=\mathrm{s})$ megőriztem.

18. A II-2. Böszörményi szójegyzék szövege betü- és tördeléshü átírásban a következö:

[recto]

\section{Annô 1782. Die $17^{\mathrm{ma}}$ Aprilis, fub Se- dria Diftrictûs Privilegiatorum Oppidorum Haj-} donicalium Caufarum Criminalium Reviforia in Oppido Böfzörmény celebrata, Confignatio Terminorum, \& Vocum, quibus Fures Nundinales, vulgò 'Sivány, feu Vásári Tolvaj, in mutuo colloquio, occafione patrandorum furtorum uti confueverunt.

\section{Peculiares Voces Fu- Interpretatio Hunga-}

rum nundinalium.

\begin{tabular}{|c|c|c|c|c|c|}
\hline 1. Fejes & - & - & - & - & Tißzt Úr. \\
\hline Kútya & - & - & - & - & ('Siványok közt. \\
\hline Tifztartó & & - & - & - & Második Személly az feö \\
\hline Rikkantó & & - & - & - & Katsa, vagy Rútza. \\
\hline 5. Sógor & - & - & - & - & Német. \\
\hline 6. Ördög & - & - & - & - & Lakat. \\
\hline
\end{tabular}




\begin{tabular}{|c|c|c|c|c|c|c|}
\hline 7. & Fasék & - & - & - & - & Fély \\
\hline 8. & Lobogó & - & - & - & - & Kefzkenö. \\
\hline 9. & Topánka & & - & - & - & Bor, Pálinka. \\
\hline 10. & Topánkás & sodni & - & - & - & Réfzegeskedni. \\
\hline 11. & Fültölö & - & - & - & - & Pipa. \\
\hline 12. & Szürhord & & - & - & - & Kondás \\
\hline 13. & Gagyi & - & - & - & - & Arany. \\
\hline 14. & Nagy Viz & & - & - & - & Sokaság a’ Vásárban. \\
\hline 15. & Sivany & - & - & - & - & Tolvaj. \\
\hline 16. & Perge & - & - & - & - & Kotfi, vágy Szekér \\
\hline 17. & Leves & - & - & - & - & Ezült pénz. \\
\hline 18. & Komnyik & & - & - & - & Orgazda, \\
\hline 19. & Rút Emb & & - & - & - & Hóhér. \\
\hline 20. & Kanaforia & & - & - & - & Akaðztófa. \\
\hline 21. & Meg - rúh & á́zni & & - & - & Verni, vagy csapni. \\
\hline 22. & Rúhi & - & - & - & - & Csapás. \\
\hline 23. & Púczika & & - & - & - & Rúha. \\
\hline 24. & Jordán & - & - & - & - & ’Sidó. \\
\hline 25 . & Czaffka & - & - & - & - & Kúrva. \\
\hline 26. & Balék & - & - & - & - & Az Ura. \\
\hline 27. & Kafzakolı & & - & - & - & Öfzve fzoritani a’ Vásárt. \\
\hline 28. & Nyalavi & & - & - & - & Az újj ’Siványok kozt leg \\
\hline 29. & Szúfzogó & & - & - & - & Difznó. $\quad$ (jobb. \\
\hline 30. & Kúxi & - & - & - & - & Vásár. \\
\hline 31. & Czaff & - & - & - & - & Egy forintos. \\
\hline 32. & Vágván & - & - & - & - & Bitsak, vagy Penna czillús. \\
\hline 33. & Czoltovaj & & - & - & - & Fizes. \\
\hline 34. & Csatsogó & & - & - & - & Kútya. \\
\hline 35. & Hontirozc & & - & - & - & Tagad. \\
\hline 36. & Nehadúvé & & - & - & - & Ki ne kiáldsd. \\
\hline 37. & Paráz & - & - & - & - & Erfzény nélkül pénz a’ ZCeb- \\
\hline 38. & Kigyó & - & - & - & - & Tüfzö. $\quad$ (be \\
\hline 39. & Paribó & - & - & - & - & Mente. \\
\hline
\end{tabular}

[verso]

40. Gyertyázz

41. Fel - tévö

42. Fel - rántó -

43. Lábra való

44. Rajzolni -

45. Kapkodás

\begin{tabular}{l|l} 
- & Vigyázz. \\
- & Kalap. \\
Cfizma. \\
- & Nadrág. \\
- & Lopni. \\
Kankó.
\end{tabular}




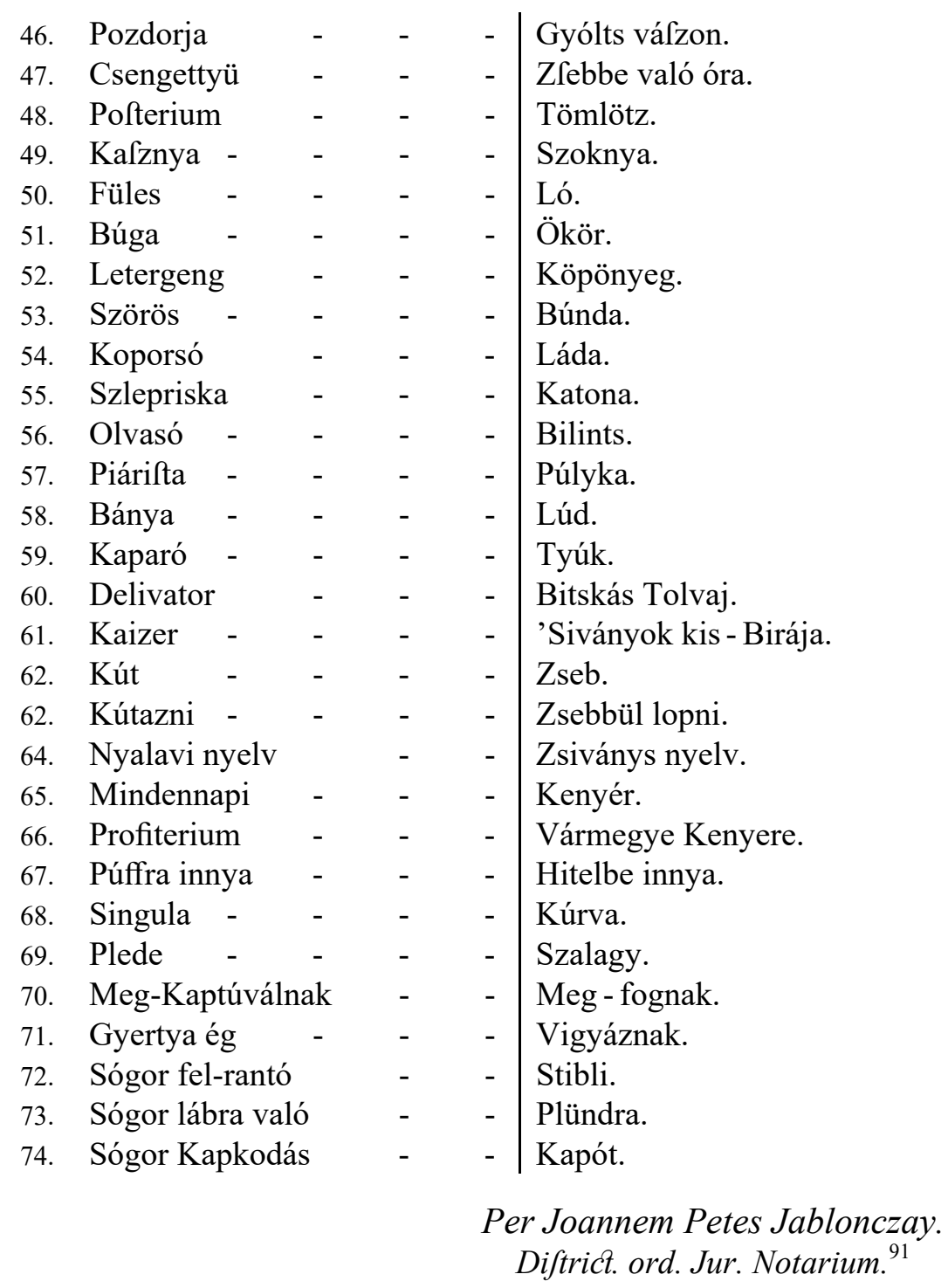

19.1.1. A II-2. Böszörményi szójegyzék egy részéről fotó a következő publikációban található: VARJASI 2015: 171.

19.1.2. A II-2. Böszörményi szójegyzék teljes fakszimiléje a következő helyeken érhetö el: http://mnytud.arts.unideb.hu/szleng/regi/zsivanyny_1782.pdf, VARJASI 2018: 114-115.

${ }^{91}=$ Per Joannem Petes Jablonczay. Districtus ordinarium Juratum Notarium 'Jablonczay Petes János. a Kerület hites főjegyzője által'. 
19.2. A II-2. Böszörményi szójegyzék szövegét többször publikálták (jobbára olyan cikkekben, amelyek mindössze a korábbi közlemények hibáit javították ki, vagy a szójegyzék anyagának csak egy részét mutatták be): ${ }^{92}$

1. DUGONICS ANDRÁS 1794. Jeles történetek. Mellyeket a’ magyar játék-színre alkalmaztatott DUGONICS ANDRÁs királyi oktató. Elsö könyv. Pesten, Füskúti Landerer Mihály kőltségével és bötüivel. 270-274. (A szójegyzék az Etelka Karjelben 12. lábjegyzete.)

1.1. SIMAI ÖDÖN 1903. A magyar tolvajnyelv legelső gyüjteménye. $M a$ gyar Nyelvőr 32: 399-401. (SIMAI DUGONICS munkájából közli a szójegyzéket.)

2. [Név nélkül] 1908. Tolvaj-nyelv. Budapesti Hirlap 28/91 (1908. április 14.): 25. (MOENICH KÁROLY, Székesfehérvár nyugalmazott levéltárosa bocsátotta a lap rendelkezésére a szójegyzéket, amit az újságban modernizált helyesírással tettek közzé.)

3. A SZERKESZTŐSÉG 1915. A magyar tolvajnyelv legelső gyüjteménye. Magyar Nyelvőr 44: 140. (KEMÉNY LAJOS kassai levéltárostól került a nyomtatvány a szerkesztőséghez, akik a SIMAI-féle közlés (1.1.) néhány adatát igazították helyre a hozzájuk eljuttatott példány segítségével.)

4. IMPLOM JÓZSEF 1957. Legrégibb tolvajnyelvi szójegyzékünk. Magyar Nyelv 53: 270-272. (IMPLOM csak SIMAI cikkének (1.1.) a helytartótanácsi nyomtatványtól eltérő formában közölt helyeit adja meg.)

5. KARCSAI-KulCSÁR IMRE 1964. Fejes, buga meg a többiek. (Kétszáz éves tolvajnyelvszótár). Kisalföld 20/172 (1964. július 24.): 3. (A újságcikkbe a hajdani mosonmagyaróvári vásárok ürügyén szőtte bele a zsiványnyelv szavait a szerző, de nem ismervén ezek pontos jelentését, írása nem több puszta érdekességnél.)

20. A Helytartótanáccsal közvetlen kapcsolatban álló helyi hatóságok a hozzájuk érkezett rendelkezéseket (gyakran magyarra fordítva, rövidítve) kéziratos másolatokban továbbították az alájuk rendelt településeknek, ahol a megkapott körleveleket bemásolták a helyi protocollum currentaliumokba. 1782 kora nyarán ezt az utat járta be a Jablonczay Petes János kerületi főjegyző aláírásával kibocsátott nyomtatott szójegyzék is, amely többszörös másolások után számos város körrendeleti jegyzőkönyvébe belekerült. A BöszSzj.II-2. ezen nyomtatottból immáron ismét kézírásossá vált (és ennek során nem kevés másolási hibát, szövegromlást összeszedett) példányait önálló, az adott településen keletkezettnek hitt szójegyzékként fedezték fel a kutatók a 20. században, és többször is közzétették a BöszSzj.II-2. helyi variánsait, a korábbi közleményeket nem is okvetlenül ismerve (vö. CSEFKÓ 1925: 71-72; BÁRCZI 1932: 8-9, 1942: 73 és 1956: 228; SCHEIBER 1956: 230).

\footnotetext{
${ }^{92} \mathrm{Az}$ itt megadott publikációkat az irodalomjegyzék nem tartalmazza.
} 
Az egyes települések körrendeleteinek jegyzőkönyveit átnézve bizonyára számos további másolat is elökerülne, nekem a következő protocollum currentaliumokban megőrződött korabeli, azaz 1782-es bejegyzésekről (továbbá ezeknek az itt felsorolt közzétételeiröl) van tudomásom: ${ }^{93}$

1. Békés: Országos Széchényi Könyvtár, jelzete: „Fol. Hung. 1581.” 4. füzet. $45 \mathrm{v}-46 \mathrm{r}$ lap.

1.1. IMPLOM JÓZSEF 1957. Legrégibb tolvajnyelvi szójegyzékünk. Magyar Nyelv 53: 270-272. (IMPLOM egy VERESS ENDRE által készített másolat, és nem az eredeti alapján közli a Békésen bejegyzett szöveg eltéréseit.)

1.2. ZOLNAY VILMOS-GEDÉNYI MiHÁLY 1945-1967. A magyar fattyúnyelv szótára. I. (Kézirat). Budapest. 0227-0232. (ZoLNAYék az eredeti békési kézirat alapján, IMPLOM közleményét helyreigazítva közlik a szójegyzéket.)

2. Füzesgyarmat: MNL BéML V. A. 314. a. 19. doboz. Currens könyv 1782. év. 101-102. (103-104.) oldal.

3. Jászárokszállás: MNL JNSzML V.901. Jászárokszállás város tanácsának iratai. Prothocollum Currentalium 1781-1784. 126-168. lap.

3.1. HOFFMANN TAMÁS 1956. Zsivány-argot 1782-ből. Magyar Nyelv 52: 89-91.

4. Jászberény: MNL JNSzML V.1.d. Jászberény város tanácsának iratai. Körlevelek jegyzőkönyve. Prothocollum Currentalium 1781-1783. 124-126. lap.

5. Kiskunfélegyháza: MNL BKML V. 101. c. Kiskunfélegyháza Város Tanácsának iratai. Körlevelek, hirdetések 1748-1848. Körlevelek jegyzőkönyve (Protocollum Currentalium) 1781-1782 T. IX. Fasc. 4. Prot. 4. 103-105. lap.

5.1. [Név nélkül] 1982. Gagyi, perge és társai. Petöfi Népe 37/107 (1982. május 9.): 4. (A cikk részleteket közöl a szójegyzékből.)

6. Kiskunhalas: MNL BKML V. 201. c. Kiskunhalas Város Tanácsának iratai. Körlevelek jegyzőkönyvei és közhirdetmények 1732-1850. X. kötet 17811782. 161-162.

6.1. NAGY CZIROK LÁSZLÓ 1965. Betyárélet a Kiskunságon. Budapest, Magvető Kiadó. 326-328.

6.2. NAGY CZIROK LÁSZLÓ 2002. Kiskunhalasi krónika. Töredékek Kiskunhalas múltjából. A város néprajza, története, anekdotái a szájhagyomány és régi irások alapján. Thorma János Múzeum Könyvei 13. Kiskunhalas, Thorma János Múzeum-Halasi Múzeum AlapítványKiskunhalas Történeti Kutatása Közalapítvány. 178.

7. Kisújszállás: MNL JNSzML V.201.d. Kisújszállás város tanácsának iratai. Körlevelek jegyzőkönyve. Prothocollum Currentalium 1778-1782. Currenta-

${ }^{93} \mathrm{Az}$ itt megadott publikációkat az irodalomjegyzék nem tartalmazza. 
les a die 20a Mensis May Anni 1782 usque dein 19ata mensis 7bris anni 1782. 29. lap.

8. Kunhegyes: MNL JNSzML V.1701.c. Kunhegyes város tanácsának iratai. Körlevelek jegyzőkönyve. Prothocollum Currentalium 1781-84. 204-205. lap.

9. Kunmadaras: MNL JNSzML V.1801.c. Kunmadaras város tanácsának iratai. Körlevelek jegyzőkönyve. Prothocollum Currentalium 1781-1783. 232-233. lap.

10. Kunszentmárton: MNL JNSzML V.1901.c. Kunszentmárton város tanácsának iratai. Körlevek jegyzőkönyve. Prothocollum Currentalium 1780-83. Protocollum Currentale № 17. 89-91. lap.

11. Makó: MNL CSML ML V. 1. c. 3. k. Körrendeletek jegyzőkönyvei (currensek) 1782. 77 lap.

11.1. VíGH ZOLTÁN 1989. Adatok Csanád vármegye közbiztonságáról a feudalizmus utolsó évszázadában. Tanulmányok Csongrád megye történetéböl 14: 77-102.

12. Szabadszállás: MNL BKML V.376. a - Szabadszállás nagyközség iratai (1819-1871-ig mezőváros); A mezőváros feudális kori iratai (1622) 16921857. 3. sorozat - Külön kezelt tanácsi iratok. 45. doboz. Körlevelek jegyzőkönyve 1781-1782. 255-256.

13. Túrkeve: MNL JNSzML V.501.c. Túrkeve város iratai. Körlevelek jegyzökönyve. Prothocollum Currentalium 1780-83. 602-605. lap.

13.1. GYÖRFFY [0: GYÖRFFY] ISTVÁN 1910. Tolvajszótár 1782-böl. Magyar Nyelvör 39: 328-329.

14. Anno 1782 az Hajdú Városokban meg fogattatott bizonyos sereg vásári tolvajok között, a lopás mesterségének könnyebb üzése végett gyakoroltatni szokott némely szóknak le írása. (BALASSA JÓZSEF a Lantos r. t. könyvesboltjában bukkant rá 1780 és 1810 közötti bejegyzések között a szójegyzékre egy a bolt tulajdonát képező könyvben, mely „,Gabrielis Gúlátsy de Eadem” tulajdonában volt hajdan. Ennek a kéziratos könyvnek a meglétéről nincs tudomásom, a szójegyzéket BALASSA közzétételéből ismerjük.)

14.1. BALASSA JÓZSEF 1924. A magyar tolvajnyelv legrégibb emléke. Magyar Nyelvör 53: 5-8.

14.1.1. ZOLNAY VILMOS-GEDÉNYI MiHÁLY 1945-1967. A magyar fattyúnyelv szótára. I. (Kézirat). Budapest. 0231-0232.

14.2. BALASSA JózSEF 1924. A régi magyar tolvajnyelv. Detektiv Szemle 6/4 (1924. április 5.): 10-11.

14.3. BALASSA JÓZSEF 1924. A magyar tolvajnyelvröl. In: SZIRMAY ISTVÁN, A magyar tolvajnyelv szótára. Összeállitotta SZIRMAY ISTVÁN „A Rend" munkatársa. Bevezető tanulmánnyal ellátta DR. BALASSA JÓZSEF a „Magyar Nyelvőr” szerkesztője. (Mindent Tudok Könyvtár 16. sz.) Budapest, Béta Irodalmi Részvénytársaság, é. n. 3-14. (A szójegyzék a 7-9. oldalon található.) 


\section{Rövidítések}

BöszSzj. = Böszörményi szójegyzékek

BöszSzj.I. = I. Böszörményi szójegyzék

BöszSzj.II. = II. Böszörményi szójegyzékek

BöszSzj.II-1. = II-1. Böszörményi szójegyzék

BöszSzj.II-2. = II-2. Böszörményi szójegyzék

EgriSzj. = Egri szójegyzékek

EgriSzj.I. = I. Egri szójegyzékek

EgriSzj.I-1. = I-1. Egri szójegyzék

EgriSzj.I-2. = I-2. Egri szójegyzék

EgriSzj.I-3. = I-3. Egri szójegyzék

EgriSzj.II. = II. Egri szójegyzék

MiskSzj. = Miskolci szójegyzék

$\mathrm{BFL}=$ Budapest Főváros Levéltára

MNL BaML $=$ Magyar Nemzeti Levéltár Baranya Megyei Levéltára

MNL BéML = Magyar Nemzeti Levéltár Békés Megyei Levéltára

MNL BKML = Magyar Nemzeti Levéltár Bács-Kiskun Megyei Levéltára

MNL CSML ML = Magyar Nemzeti Levéltár Csongrád Megyei Levéltár Makói Levéltára

MNL FML = Magyar Nemzeti Levéltár Fejér Megyei Levéltára

MNL GyMSMGyL = Magyar Nemzeti Levéltár Győr-Moson-Sopron Megye Győri Levéltára

MNL GyMSMGyL ML = Magyar Nemzeti Levéltár Győr-Moson-Sopron Megye Györi Levéltára Mosonmagyaróvári Fióklevéltára

MNL HBML = Magyar Nemzeti Levéltár Hajdú-Bihar Megyei Levéltára

MNL HBML HbFl = Magyar Nemzeti Levéltár Hajdú-Bihar Megyei Levéltára Hajdúböszörményi Fióklevéltára

MNL HML = Magyar Nemzeti Levéltár Heves Megyei Levéltára

MNL JNSzML = Magyar Nemzeti Levéltár Jász-Nagykun-Szolnok Megyei Levéltára

MNL NML $=$ Magyar Nemzeti Levéltár Nógrád Megyei Levéltára

MNL OL = Magyar Nemzeti Levéltár Országos Levéltára

MNL SML = Magyar Nemzeti Levéltár Somogy Megyei Levéltára

MNL SzSzBML = Magyar Nemzeti Levéltár Szabolcs-Szatmár-Bereg Megyei Levéltára

MNL TML = Magyar Nemzeti Levéltár Tolna Megyei Levéltára

MNL VeML = Magyar Nemzeti Levéltár Veszprém Megyei Levéltára

MTA KIK = Magyar Tudományos Akadémia Könyvtár és Információs Központ

OSZK = Országos Széchényi Könyvtár

PMKL = Piarista Rend Magyar Tartománya Központi Levéltára 


\section{Irodalom}

Államrendőrség $1911=$ [Név nélkül] 1911. A tolvajnyelv szótára. Melléklet az „Államrendőrség” 44-ik rendkivüli számához. Budapest, A Budapesti Államrendőrség Fökapitányságának Bünügyi Osztálya.

BÁRCZI GÉZA 1932. A „pesti nyelv”. A Magyar Nyelvtudományi Társaság Kiadványai 29. Budapest.

BÁRCZI GÉZA 1942. Jegyzetek a budapesti népnyelvröl. Magyar Népnyelv 4: 71-89.

BÁRCZI GÉZA 1956. Legrégibb tolvajnyelvi szójegyzékünk. Magyar Nyelv 52: 228-230.

BERKES KÁLMÁN 1888. A tolvaj élet ismertetése. Budapest, Magyar Királyi Egyetemi Könyvnyomda.

[BoRoss JÓZSEF-SzŰTs LÁsZló] 1987. A mai magyar argó kisszótára. Összeállította BOROsS JózSEF-SzÜTS [э: SzÜTS] LÁsZló. Budapest, Idegenforgalmi, Propagandaés Kiadóvállalat, é. $\mathrm{n}$.

CSEFKÓ GYULA 1925. Adalékok tolvajnyelvi szótáraink könyvészetéhez. Magyar Nyelv 21: 70-72.

EMBER GYÖZÖ 1940. A M. Kir. Helytartótanács ügyintézésének története. 1724-1848. Budapest, A M. Kir. Országos Levéltár kiadványa.

GREGOR FERENC 1972. Észrevételek a magyar tolvajnyelv néhány szlovák eredetủ szaváról. Magyar Nyelv 68: 160-169.

HeINLEIN IsTVÁN 1908. Egri tolvajnyelv a XIX-dik század elejéről. Magyar Nyelv 4: 268-269.

HofFMANN, OTTÓ-KIS, TAMÁs 2009. Wörterverzeichnis der Diebessprache aus Pinkafeld (Ungarn). In: EFInG, CHRISTIAN-LESChBER, CoRINNA szerk., Geheimsprachen in Mittel- und Südosteuropa. Frankfurt am Main-Berlin-Bern-Bruxelles-New YorkOxford-Wien, Peter Lang. 103-126.

JENŐ SÁNDOR-VETŐ IMRE 1900. A magyar tolvajnyelv és szótára. Irta és gyüjtötte: JENŐ SÁNDOR és VETŐ IMRE. Budapest, A szerzők sajátja.

KIs TAMÁs 2001. Német tolvajnyelvi szójegyzék a 18. századból. Folia Uralica Debreceniensia 8: 251-262.

KIS TAMÁs 2002. XVIII. századi zsiványnyelvi szójegyzékeink. Börtönügyi Szemle 21/2 (2002. június): 67-76.

KIS TAMÁs 2013. Zsiványnyelvi emlékek Böszörményben. Hajdúsági Tükör 6/1 (2013. március 15.): 12-14.

KIS TAMÁs 2020. Két újabb 18. századi zsiványnyelvi szójegyzék Egerből. Publicationes Universitatis Miskolcinensis, Sectio Philosophica 24/1: 274-286.

LeHr AlBerT 1914. A betyárság kifejezései. Magyar Nyelv 10: 45-47, 90.

NAGY SÁNDOR 1970. Zsivány nyelv a XVIII. században. Múzeumi Kurír 2. (1970. február): 34-36.

NAGY SÁNDOR 1990. A hajdúkerületi törvényszék büntetéskiszabási gyakorlata lopás miatt indított bünügyekben 1757-1850. A Hajdúsági Múzeum Évkönyve 7: 67-115.

SCHEIBER SÁNDOR 1956. Legrégibb tolvajnyelvi szójegyzékünk. Magyar Nyelv 52: 230. 
SCHRAM FERENC 1962. Egy 1775-i tolvajnyelvi szójegyzék. Magyar Nyelv 58: 107-109.

SIKLÓSSY LÁSZló 1933. A betyár beszéde. Pesti Hirlap Vasárnapja 55/14 (1933. április 2.) $22-24$.

TORONYAI KÁROLY 1862. A rablóknak, tolvajoknak és kozákoknak együttvaló hamis és zavaros beszédeik, hasonlóan hamis és titkos cselekedeteik felfedezéseül összeiratott és kiadattatott a köznépnek ovakodási hasznára, és a rosz emberektöl való örizkedéseikre Toronyai Károly által Békés Csabán. Pest.

[TÖMÖRKÉNY IsTVÁN-CSERZY MiHÁly (?)-BÉKEFI ANTAL (??)] 1898. Betyárlegendák. Az alföldi rablóvilág történetei. Szeged, Engel Lajos kiadása.

TÖRÖK GÁBOR 1957. Legrégibb tolvajnyelvi szójegyzékünk. Magyar Nyelv 53: 273-274.

VARJASI IMRE 2015. Érdekességek a Hajdúkerület iratanyagából. A Hajdú-Bihar Megyei Levéltár Évkönyve 34: 161-175.

VARJASI IMRE 2016. Eleink öröksége. Néhány érdekesség a Hajdúkerület büntetőbíráskodásából. Hajdúsági Tükör 9/2 (2016. június 20.): 5-7.

VARJASI IMRE 2018. „Zsivány Nyelv — Zsivány Szók”. Jogtörténeti-nyelvtörténeti emlékek a Hajdúságban. In: MEGYERI-PÁLFFI ZoLTÁn szerk., A jogszolgáltatás története Hajdúböszörményben. Debrecen, Debreceni Törvényszék. 112-115.

\section{Glossaries of Outlaw Language from Böszörmény}

The earliest authentic records of Hungarian cant are represented by glossaries dated from the final third of the 18th century, compiled in the process of criminal lawsuits against market thieves in Miskolc, Eger and [Hajdú]Böszörmény. The first glossary from Böszörmény was made in 1776 with its handwritten and print versions made in 1782. This paper is the first collective, philologically-reliable publication of the Böszörmény glossaries, which also introduces additional information related to these glossaries.

Keywords: outlaw language, cant, market thieves, linguistic record, glossary, Böszörmény

Kis Tamás

ORCID: 0000-0002-9500-7525

Debreceni Egyetem tkis62@gmail.com 